NOTES

\title{
APPLYING FRAUDULENT CONVEYANCE LAW TO LEVERAGED BUYOUTS
}

\author{
RAYMOND J. BLACKWOOD
}

\section{INTRODUCTION}

In April 1990, Marty Lipton of the New York law firm Wachtell, Lipton, Rosen \& Katz surprised Henry Kravis of Kohlberg Kravis Roberts \& Co. (KKR) while the two men were having lunch. ${ }^{1}$ Mr. Kravis was troubled by the financial difficulties of RJR Nabisco, Inc. (RJR), which had incurred more than $\$ 20$ billion of debt ${ }^{2}$ during its 1989 "leveraged buyout" $(\mathrm{LBO})^{3}$ by a group of investors led by KKR. ${ }^{4}$ The KKR group had formed RJR Holdings Corp., which in turn had created the wholly-owned subsidiary RJR Holdings Group, Inc., which in turn had created the wholly-owned subsidiary RJR Acquisition Corp. ${ }^{5}$ KKR thereafter had effectuated the RJR LBO through the following steps: (1) RJR Holdings Group had purchased $74 \%$ of the outstanding RJR stock through a public tender offer by paying $\$ 109$ per share in cash; ${ }^{6}$ and (2) after gaining control of RJR, RJR Holdings

1. George Anders, $K K R$ in Peril: The Fight to Save RJR, WALL ST. J., Apr. 16, 1992, at B1; see also GEORGE ANDERS, MERCHANTS OF DEBT: KKR AND THE MORTGAGING OF AMERICAN BUSINESS 252, 263 (1992).

2. Anders, supra note 1 , at $\mathrm{B1}$.

3. One court has defined a leveraged buyout as follows:

A leveraged buy-out occurs when a group of investors, usually including members of a company's management team, buy the company under financial arrangements that include little equity and significant new debt. The necessary debt financing typically includes mortgages or high risk/high yield bonds, popularly known as "junk bonds." Additionally, a portion of this debt is generally secured by the company's assets. Some of the acquired company's assets are usually sold after the transaction is completed in order to reduce the debt $\mathrm{m}$ curred in the acquisition.

Metropolitan Life Ins. Co. v. RJR Nabisco, Inc., 716 F. Supp. 1504, 1505 n.1. (S.D.N.Y. 1989).

4. Anders, supra note 1 , at B1.

5. See Metropolitan Life, 716 F. Supp. at 1505 n.2.

6. Abraham J. Briloff, $L B O s$ and $M B O s$ in the Takeover Alphabet Soup: Some Questions for Lawyers, Answers from an Accountant, 15 J. CoRP. L. 171, 174, 179 (1990). 
Group had forced a merger between RJR and RJR Acquisition Corporation (a shell subsidiary formed solely for the purpose of merging into RJR). ${ }^{7}$ Of the $\$ 20.3$ billion cash that had been spent in the tender offer, only $\$ 1.5$ billion had come from KKR investors; the remainder of the cash had been raised through bank loans and through the sale of increasing rate notes by the investment banking firm of Drexel Burnham Lambert. ${ }^{8}$ After the merger, not only did RJR have on its books the $\$ 20.3$ billion in debt incurred in the tender offer, but the lending banks possessed a security interest in all of RJR's assets in order to support the $\$ 12.2$ billion of bank debt. ${ }^{9}$

So in the Spring of 1990 , during a seemingly routine lunch meeting, Mr. Lipton informed Mr. Kravis that a bankruptcy filing was perhaps necessary for RJR in the near future..$^{10} \mathrm{Mr}$. Lipton offered the services of his law firm for what would have been the largest bankruptcy filing ever. ${ }^{11}$ Although Mr. Kravis eventually resolved RJR's crisis without filing for bankruptcy protection, the mere thought of RJR going into bankruptcy was staggering. ${ }^{12}$ Not only would KKR, its investors, and the LBO bank lenders have suffered a huge financial loss, but the bankruptcy process would have been long and arduous.

If $\mathrm{RJR}$ were to have filed for bankruptcy protection, the creditors of RJR who did not take part in the LBO might have attacked the LBO as a fraudulent conveyance. ${ }^{13}$ Applying fraudulent conveyance law to the RJR LBO would have been a challenging task because the fraudulent conveyance statutes are ancient and simplistic whereas LBOs are new and complex. If the RJR LBO were ruled a fraudulent conveyance, the bankruptcy

RJR stock had recently been trading at around $\$ 50$ per share. Therefore, the purchase price in the tender offer was approximately a $100 \%$ premium above market. See id. at 178 n.37.

7. Id. at 175 . In the merger, each share of RJR stock not owned by RJR Holdings Group was exchanged for 2.803 shares of cumulative exchangeable preferred stock in RJR Holdings Group and $\$ 31.14$ face amount of RJR Holdings Corp. senior convertible debentures. See id.

8. Id. at 174 .

9. Id.

10. Anders, supra note 1 , at B1.

11. Id.

12. Id.

13. See 11 U.S.C. $\$ 548$ (1988); UNIF. FRAUDULENT CONVEYANCE ACT, 7A U.L.A. 427 (1918), superseded by UNIF. FRAUDULENT TRANSFER ACT, 7A U.L.A. 639 (1985). 
judge would have wide discretion in fashioning an equitable remedy. ${ }^{14}$ The secured LBO lenders might have had their security interests voided, ${ }^{15}$ and all LBO lenders probably would have been subordinated to the non-LBO debt in the bankruptcy reorganization. ${ }^{16}$ The LBO lenders might have had their loans completely rescinded, and the former RJR shareholders might even have been liable for the money that the KKR group paid for their shares during the $\mathrm{LBO}^{17}$

Although the RJR LBO was the largest LBO ever, its structure is representative of the typical LBO. In a typical LBO, a group of investors, such as the KKR group, gains complete control of a corporation with little or no capital investment of its own. The investors are able to accomplish this feat through a series of complex transactions that results in the corporation essentially buying itself for the benefit of the investors. The investors convince lenders to loan them the bulk of the purchase price of the corporation by giving the lenders security in all or most of the corporation's assets. In this way, the investors convert much of the equity of the corporation into debt, cash out the prior stockholders at a premium, and gain control of a highly leveraged corporation.

The dramatic increase in the corporation's debt-to-equity ratio greatly increases the risks involved in running the company. If the corporation is able to pay off the LBO debt, the investors enjoy huge profits because they have purchased full equity participation in a successful company with a small expenditure of their own funds. ${ }^{18}$ The investors can then take the corporation public and

14. In re Revco D.S., Inc., 118 B.R. 468, 511 (Bankr. N.D. Ohio 1990) (appendix containing the Preliminary Report of Examiner Professor Barry L. Zaretsky, July 16, 1990); see also Barry L. Zaretsky, Final Report of Examiner Professor Barry L. Zaretsky 201-30 (Dec. 17, 1990) (unpublished, on file with author) [hereinafter Zaretsky, Final Report]. This Note will not discuss the many issues involved in fashioning a remedy when an LBO is found to have been a fraudulent conveyance; however, the two reports cited in this footnote contain an excellent discussion of the remedies available.

15. See Revco, 118 B.R. at 516-25; Zaretsky, Final Report, supra note 14, at 220-28.

16. Zaretsky, Final Report, supra note 14, at 227.

17. The issue of shareholder liability in a fraudulent conveyance action arising out of an LBO will not be discussed in this Note. For a discussion of this issue, see Wieboldt Stores v. Schottenstein, 94 B.R. 488, 500-03 (N.D. Ill. 1988); Zaretsky, Final Report, supra note 14 , at $231-37$.

18. KKR, for instance, paid only $\$ 1.5$ billion of its own cash for RJR, when the total purchase price was $\$ 26.4$ billion and when, even before the tender offer, the stock market had valued RJR at approximately $\$ 13$ billion. See Briloff, supra note 6, at 173-75; 
realize substantial profits. On the other hand, if the corporation experiences unexpected setbacks or if the economy in general slows down, the leveraged company may soon find itself in bankruptcy. In a bankruptcy proceeding, the unsecured creditors of the corporation will receive little or nothing for their claims because these claims have been subordinated to large amounts of debt secured by all of the corporation's assets. However, if the LBO is held to be a fraudulent conveyance, the LBO debt may be subordinated to the non-LBO debt.

As more and more LBO corporations have sought bankruptcy protection, the unsecured creditors of LBO companies and creditor representatives have increasingly instituted suits based on fraudulent conveyance laws. These laws originated in sixteenth-century England, continued in the law of the American states, and eventually were incorporated into American bankruptcy law. Fraudulent conveyance law has traditionally been applied in contexts that are much less complex than that of the LBO. As a result, much controversy has surrounded the issues of whether the fraudulent conveyance laws should be applied to LBOs at all, and if so, what analysis should be used to determine whether LBOs are voidable as fraudulent conveyances. This Note demonstrates that LBO transactions are properly within the province of fraudulent conveyance law. Moreover, although the complexity of an LBO creates difficult valuation problems, coherent fraudulent conveyance standards can be developed for LBO transactions.

Part I of this Note provides background information on LBOs and fraudulent conveyance law. Part II addresses a groundbreaking law review article which argues that LBOs should be exempt from fraudulent conveyance law. After considering the policy implications involved in exempting LBOs from fraudulent conveyance law, Part II shows why LBOs are clearly within the language of the fraudulent conveyance statutes. Part II also posits an alternate justification for applying fraudulent conveyance law to LBOs based on legislative ratification. Part III shows how fraudulent conveyance law is applied to LBOs. Part IV concludes that viable fraudulent conveyance standards can be developed for LBOs, despite the belief of certain commentators that judges are incapable of applying such standards. 


\section{BACKGROUND}

\section{A. Background Information on LBOs}

An LBO is a complex series of transactions that rearranges a corporation's financial structure without altering the nature of the company's business. An LBO changes the ownership of the corporation and focuses the corporation on the preeminent goal of servicing the large LBO debt. Although there are many ways of structuring LBOs, the most common structure involves the merger of the operating company with a shell corporation formed for the sole purpose of accomplishing the LBO. $^{19}$ The LBO investors form the acquisition shell and capitalize it with their minimal equity contribution. A complex series of transactions effects a merger of the shell and the operating company. Ultimately, the shareholders of the company are bought out in a transaction financed almost entirely by debt. Usually senior secured bank debt is insufficient to finance the entire transaction, and "mezzanine financing"- unsecured subordinated debt (often called "junk bonds") or preferred stock-supplies the remainder of the money needed for the LBO. ${ }^{20}$ Whether or not the acquisition shell or the target company initially incurs the debt, after the merger is effected the debt belongs solely to the target and is almost always secured by all of the target's assets. ${ }^{21}$

\section{B. The General Evolution of Fraudulent Conveyance Law}

In contrast to the modern emergence of LBOs, fraudulent conveyance laws date back to 1571, when the English Parliament enacted a law that voided all transfers by debtors whose purpose was to hinder, delay, or defraud their creditors." The "Statute of 13 Elizabeth" was transferred into early American jurisprudence

19. Matthew T. Kirby et al., Fraudulent Conveyance Concerns in Leveraged Buyout Lending, 43 Bus. LAW. 27, 34 (1987).

20. Richard M. Cieri et al., An Introduction to Legal and Practical Considerations in the Restructuring of Troubled Leveraged Buyouts, 45 BUs. LAW. 333, 341 (1989). In the case of the RJR LBO, both "junk bonds" and preferred stock were used to finance it. See Briloff, supra note 6, at 175.

21. Kirby et al., supra note 19 , at 34-35.

22. Statute of Fraudulent Conveyances, 13 Eliz., ch. 5 (1571) (repealed by The Law of Property Act, 15 Geo. 5, ch. 20, \$172 (1925)); see Douglas G. Baird \& Thomas H. Jackson, Fraudulent Conveyance Law and Its Proper Domain, 38 VAND. L. REV. 829, 829-30 (1985). 
through state common and statutory law. Because directly proving an actual intent to defraud was very difficult, Anglo-American courts developed the "badges of fraud" doctrine, under which certain suspicious circumstances were accepted as sufficient proof to support a finding that a transfer was made with fraudulent intent. ${ }^{23}$ For example, if an insolvent debtor transferred assets and received little or nothing in return, fraudulent intent was presumed and the transaction was voidable as a fraudulent conveyance.

In an attempt to create a uniform law of fraudulent conveyance, in 1918 the Conference of Commissioners on Uniform State Laws promulgated the Uniform Fraudulent Conveyance Act (UFCA), ${ }^{24}$ which sought to codify the "better' decisions applying the Statute of 13 Elizabeth."2s The UFCA voids all conveyances made by debtors with actual intent to defraud their creditors, and sets forth three per se situations in which fraudulent intent is presumed.

Under the Bankruptcy Act of 1898, the trustee in bankruptcy had always been able to attack transactions based on state fraudulent conveyance law and the "Statute of 13 Elizabeth."." In 1938, the Chandler $\mathrm{Act}^{27}$ added constructive fraud provisions to the Bankruptcy Act. In 1984 the Conference of Commissioners on Uniform State Laws promulgated the Uniform Fraudulent Transfer Act (UFTA) ${ }^{28}$ to replace the UFCA. The goal of the UFTA is to

23. See, e.g., Twyne's Case, 76 Eng. Rep. 809 (K.B. 1601) (creating "badges of fraud" doctrine); Sturtevant v. Ballard, 9 Johns. 336 (N.Y. Sup. Ct. 1812) (sale of property by insolvent debtor who maintains possession for no good reason is per se a transfer made with intent to defraud).

24. 7A U.L.A. 427 (1985).

25. Frank R. Kennedy, The Uniform Fraudulent Transfer Act, 18 UCC L.J. 195, 196 (1986).

26. The "Statute of 13 Elizabeth" was incorporated in $\S 67$ of the Bankruptcy Act of 1898. See 4 William M. Collier, Collier ON BANKRUPTCY II 548.01, at 548-4 to 548-8 (Lawrence P. King ed., 15th ed. 1990) [hereinafter COLLIER ON BANKRUPTCY].

27. Pub. L. No. 75-696, 52 Stat. 840, 875-78 (1938), repealed by Bankruptcy Act of 1978, Pub. L. No. 95-598, 92 Stat. 2549, 2600-01. The fraudulent conveyance provisions are now found in $\S 548$ of the Bankruptcy Act of 1978. See 11 U.S.C. $\$ 548$ (1988) (amended by 11 U.S.C. $\S 548$ (d) (Supp. II 1990)).

28. UNIF. FRAUdULENT TRANSFER ACT, 7A U.L.A. 639 (1985). The UFTA has been enacted in 29 states: Alabama, Arizona, Arkansas, California, Colorado, Connecticut, Florida, Hawaii, Idaho, Illinois, Maine, Minnesota, Montana, Nebraska, Nevada, New Hampshire, New Jersey, New Mexico, North Dakota, Ohio, Oklahoma, Oregon, Rhode Island, South Dakota, Texas, Utah, Washington, West Virginia, and Wisconsin. Id. at 165 (Supp. 1992). No case has yet applied the UFTA to an LBO. Although modifications in the law made by the UFTA may raise interesting issues, there is no reason to believe 
eliminate the differences between state fraudulent conveyance law and section 548 of the Bankruptcy Code (section 548). ${ }^{29}$ Twentynine states have enacted the UFTA, whereas the UFCA remains in force in only nine jurisdictions. ${ }^{30}$

\section{Basic Elements of a Fraudulent Conveyance}

Although there are some differences between the UFCA, the UFTA, and section 548, they share the same basic format. ${ }^{31}$ If a debtor enters a transaction with the actual intent to defraud his creditors, then the transaction is voidable by the creditors regardless of the consideration received by the debtor in the transaction. $^{32}$

Transactions are also voidable as per se fraudulent conveyances under the constructive fraud provisions. ${ }^{33}$ These provisions all require that the consideration in a transaction fail to meet a certain standard of sufficiency. The UFCA uses a standard of "fair consideration," which is defined as "a fair equivalent" exchanged "in good faith." "reasonably equivalent value." ${ }^{35}$ In addition to requiring insufficient consideration, the transfer in question must coincide with the existence of any of the following three situations: (1) insolvency of the debtor (liabilities exceed "present fair salable value"36 or the

that the basic analysis will be any different under the UFTA than under the UFCA or under $\S 548$ of the Bankruptcy Code.

29. See Kennedy, supra note 25 , at 198-99.

30. The UFCA is still the law in the following jurisdictions: Delaware, Maryland, Massachusetts, Michigan, New York, Pennsylvania, Tennessee, the Virgin Islands, and Wyoming. UNIF. FRAUDULENT CONVEYANCE ACT, 7A U.L.A. at 136 (Supp. 1992). Alaska, Georgia, Indiana, Iowa, Kansas, Kentucky, Louisiana, Mississippi, Missouri, North Carolina, South Carolina, Vermont, and Virginia have no uniform statutes on fraudulent conveyances. See id. at 136; UNIF. FraUdULENT TRANSFER ACT, 7A U.L.A. at 165 (Supp. 1992).

31. See James F. Queenan, Jr., The Collapsed Leveraged Buyout and the Trustee in Bankniptcy, 11 CARDozo L. REV. 1, 6-8 (1989).

32. See 11 U.S.C. $\S 548(a)(1)$ (1988); UNIF. FRAudulENT ConveYANCE ACT \& 7 , 7A U.L.A. at 509; UNIF. FRAUDULENT TRANSFER ACT $\S 4(\mathrm{a})(1)$, 7A U.L.A. at 652 .

33. See 11 U.S.C. $\S 548(a)(2)$; UNIF. FRAUdulENT CONVEYANCE ACT $\S \S 2-6,7$ A U.L.A. at 442-509; UNIF. FRAUDULENT TRANSFER ACT $\S \S 2-5,7 A$ U.L.A. at 648-58.

34. UNIF. FRAUDULENT CONVEYANCE ACT $\S 3,7 A$ U.L.A. at $448-49$.

35. See 11 U.S.C. § 548(a)(2)(A); UNIF. FRAUDULENT TRANSFER ACT $\S \S 4(2), 5,7$ A U.L.A. at 652 , 658. In this Note, the term "sufficient consideration" will be used as an expedient to refer to the general concept of a required level of consideration in the constructive fraud provisions.

36. UNIF. FRAUdULENT CONVEYANCE ACT $\S 2(1), 7$ A U.L.A. at 442. 
"fair valuation"37 of the debtor's assets); (2) the debtor's business being left with "unreasonably small capital" or "unreasonably small assets"; $;$ " or (3) the debtor's belief or intent ("reasonably should have believed" in the UFTA ${ }^{40}$ ) that it is incurring debts beyond its ability to pay them as they come due. ${ }^{41}$

The main difference between section 548 and the UFCA and UFTA involves the statutes of limitation. Section 548 applies only to transactions that occur within one year prior to the filing of the bankruptcy petition, ${ }^{42}$ whereas the UFTA has a four-year statute of limitations, ${ }^{43}$ and the UFCA leaves the determination of the statute of limitations up to the states, ${ }^{44}$ which often have six-year statutes of limitations. ${ }^{45}$

Because the bankruptcy trustee can enforce the avoidance rights held by any creditor under state law at the time of the

37. 11 U.S.C. $\S 101(32)$ (A) (Supp. II 1990); UNIF. FRAUdULENT TRANSFER ACT $§ 2$, 7A U.L.A. at 648.

38. 11 U.S.C. $\S 548(\mathrm{a})(2)(\mathrm{B})(\mathrm{ii)}$ (1988); UNIF. FRAUDULENT CONVEYANCE ACT $\S 5$, 7A U.L.A. at 504.

39. Unif. Fraudulent Transfer Act § 4(a)(2)(i), 7A U.L.A. at 653.

40. Id. § 4(a)(2)(ii), 7A U.L.A. at 653.

41. 11 U.S.C. $\$ 548(\mathrm{a})(2)(\mathrm{B})(\mathrm{iii}) ;$ UNIF. FRAudulent CONVEYANCE ACT $\S 6,7 \mathrm{~A}$ U.L.A. at 507; UNIF. FRAUDULENT TRANSFER ACT $\$ 4$ (a)(2)(ii), 7A U.L.A. at 653. In challenging LBOs as fraudulent conveyances, this third requirement has not been used very often and has little independent relevance. The requirement of a "belief or intent" that the debtor is incurring debts beyond its ability to pay makes this analysis a subjective inquiry regarding the debtor's state of mind. Because LBO participants usually lack an intent or belief that the LBO will fail, plaintiffs challenging an LBO on grounds of fraudulent conveyauce find this cause of action unattractive. The UFTA's addition of the "reasonably should have believed" language would seem to make this inquiry very similar to the "unreasonably small capital" analysis, as both provisions inquire into the reasonableness of the LBO participants' financial assumptions. In the context of an LBO, this third requirement either lacks utility or recapitulates the "unreasonably small capital" analysis. Therefore, the requirement will not be discussed in this Note.

42. 11 U.S.C. \& 548(a).

43. UNIF. FRAUDULENT TRANSFER ACT $\S 9(a)$, 7A U.L.A. at 665. But see id. at 179-80 (Supp. 1992) (soine UFTA states have changed the statute of limitations, such as Alabama (limitation period unay be one, four, six, or ten years depending on section of UFTA and whether property transferred was real or personal property), California (four year linitation period with added one-year discovery rule and maxinum period of seven years), Maine (six-year period with an additional one-year discovery rule exteusion), and Montana (two-year statute of limitations)).

44. UNIF. Fraudulent CONVEYANCE ACT \$§ 11-12, 7A U.L.A. at 634-36.

45. See, e.g., Carey v. Crescenzi, 923 F.2d 18, 20 (2d Cir. 1991) (six-year limitations period for fraudulent conveyance actions in New York); Murphy v. Meritor Sav. Bank (In re O'Day Corp.), 126 B.R. 370, 392 (Bankr. D. Mass. 1991) (six-year period in Massachusetts). 
order for relief, the trustee can avail himself of the applicable state fraudulent conveyance statute and attack transactions that occurred more than a year before the commencement of the case..$^{45}$ Further, the doctrine of Moore v. Bay holds that as long as one actual creditor has a cause of action based on state fraudulent conveyance law, the trustee can avoid the transaction to the degree required to satisfy the claims of all existing creditors.

Despite the different terminology used in section 548 and state fraudulent conveyance statutes, courts have tried as much as possible to create a uniform fraudulent conveyance law. Thus, precedents under different statutes and from different jurisdictions are accorded substantial deference in an attempt to harmonize fraudulent conveyance law throughout the United States. ${ }^{48}$

\section{LBOS SHOULD NOT BE EXEMPTED FROM THE COVERAGE OF FRAUDULENT CONVEYANCE LAWS}

Because the plain language of the fraudulent conveyance statutes covers the security interest granted and the payments made when the shareholders of an LBO target are cashed out, every court that has addressed the issue has held that the fraudulent conveyance laws apply to LBOs. ${ }^{49}$ Despite this judicial consensus, Professors Douglas Baird and Thomas Jackson, in a

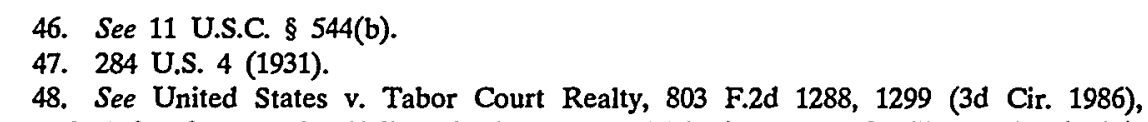
cert. denied sub nom. McClellan Realty Co. v. United States, 483 U.S. 1005 (1987); Moody v. Security Pac. Business Credit, 127 B.R. 958, 999 (W.D. Pa. 1991), affd, 971 F.2d 1056, 1068 (3d Cir. 1992); see also UNIF. FRAUDULENT CONVEYANCE ACT § 12, 7A U.L.A. at 635; UNIF. FRAUDULENT TRANSFER ACT § 11, 7A U.L.A. at 667.

49. See Lippi v. City Bank, 955 F.2d 599 (9th Cir. 1992); Mellon Bank v. Metro Communications, 945 F.2d 635, 645-46 (3d Cir. 1991), cert. denied sub nom. Committee of Unsecured Creditors v. Mellon Bank, 112 S. Ct 1476 (1992); Kupetz v. Wolf, 845 F.2d 842, 847 (9th Cir. 1988); Tabor Court Realty, 803 F.2d at 1297; Aluminum Mills Corp. v. Citicorp (In re Aluminum Mills), 132 B.R. 869, 885 (Bankr. N.D. III. 1991); Crowthers McCall Pattern, Inc. v. Lewis, 129 B.R. 992, $997-98$ (S.D.N.Y. 1991); Moody, 127 B.R. at 989 n.7; Murphy, 126 B.R. at 392; Ferrari v. Barclay's Business Credit (In re Morse Tool), 108 B.R. 389, 391 (Bankr. D. Mass. 1989); Vadnais Lumber Supply v. Byme (In $r e$ Vadnais Lumber Supply), 100 B.R. 127, 134-35 (Bankr. D. Mass. 1989); Wieboldt Stores v. Schottenstein, 94 B.R. 488, 499 (N.D. Ill. 1988); Ohio Corrugating Co. v. DPAC, Inc. (In re The Ohio Corrugating Co.) (Ohio Corrugating II), 91 B.R. 430, 434-35 (Bankr. N.D. Ohio 1988); Kaiser Steel v. Jacobs (In re Kaiser Steel), 87 B.R. 154, 160-61 (Bankr. D. Colo. 1988); Credit Managers Ass'n of Southern Cal. v. Federal Co., 629 F. Supp. 175, 179 (C.D. Cal. 1985); Anderson Indus. v. Anderson (In re Anderson Indus.), 55 B.R. 922, 926 (Bankr. W.D. Mich. 1985). 
groundbreaking law review article, have argued strenuously for exempting LBOs from the reach of fraudulent conveyance law. ${ }^{50}$ Their argument has appealed to many people in the business community who worry that a billion-dollar loan will be rescinded or subordinated simply because a judge with little or no financial acumen mistakenly finds the LBO consideration to be insufficient and the company to be insolvent at the time of the LBO. It is important to understand these concerns and to address Baird and Jackson's arguments before determining what kind of fraudulent conveyance standards should be applied to LBOs.

This Part first presents the Baird and Jackson analysis. It then summarizes the policy arguments on both sides of the LBO exemption issue. After briefly detailing how LBOs fall within the language of fraudulent conveyance statutes, Part II presents an alternate ground for denying LBOs an exemption from fraudulent conveyance law based on legislative ratification.

\section{A. The Baird and Jackson Analysis}

The cornerstone of the argument in favor of LBO exemption is a 1985 law review article by Professors Baird and Jackson. ${ }^{51}$

50. See Baird \& Jackson, supra note 22; see also Kupetz v. Wolf, 845 F.2d 842,847 (9th Cir. 1988) (citing Baird \& Jackson argument and expressing doubt that "above board" LBOs are voidable as fraudulent conveyances), aff'g Kupetz v. Continental Ill. Nat'l Bank \& Trust Co., 77 B.R. 754, 759-60 (C.D. Cal. 1987) (intimating that court would exempt LBOs from fraudulent conveyance law if asked to do so); Credit Managers, 629 F. Supp. at 179 (stating that court might hold that LBOs are exempt from fraudulent conveyance law).

These cases also raise the issue of the ability of post-LBO creditors to challenge the LBO as a fraudulent conveyance. This Note will not address the issue of post-LBO creditors' standing to assert fraudulent conveyance claims. Readers interested in this topic should compare Lippi, 955 F.2d at 606-07 (trustee may only assert fraudulent conveyance claims on behalf of post-LBO creditors if the trustee has raised a factual issue as to whether the LBO was undertaken with actual intent to defraud creditors), Kupetz, 845 F.2d at 849-50 n.16 (same), Credit Managers, 629 F. Supp. at 180-81 (only those who were creditors at the time of the LBO should be able to challenge the LBO as a fraudulent conveyance), and Ohio Corrugating II, 91 B.R. at 435 (those who become creditors after an LBO should only be able to assert fraudulent conveyance claims based on actual intent to defraud) with Ferrari, 108 B.R. at 390 (plain language of UFCA gives postLBO creditors a cause of action under both actual fraud provision and "unreasonably small capital" provision) and Queenan, supra note 31, at 21-24 (arguing that Kupetz and Credit Managers are wrong because they violate the plain meaning of $\S 5$ of the UFCA and that Ohio Corrugating II is wrong because the creditor representative enforces $\S 548$ for the benefit of all who are creditors at the time of the bankruptcy filing).

51. See Baird \& Jackson, supra note 22. 
Baird and Jackson argue that because fraudulent conveyance laws arose out of a simplistic and outdated sixteenth-century setting, applying such laws to transactions as modern and complex as the LBO is wholly inappropriate. ${ }^{52}$ As Baird and Jackson declare, "[a] firm that incurs obligations in the course of a buyout does not seem at all like the Elizabethan deadbeat who sells his sheep to his brother for a pittance." 53

Baird and Jackson first consider whether fraudulent conveyance law should be applied only to those transactions where an intent to defraud is likely. ${ }^{54}$ They then reject this principle because the constructive provisions are meant to cover other transactions such as "gifts by insolvent debtors." 55 These transactions-which are within the ambit of fraudulent conveyance law regardless of whether or not it is likely that an actual intent to defraud existed-are subject to fraudulent conveyance law because they are "inherently objectionable" since creditors would want to preclude them if they could. ${ }^{56}$ In contrast, Baird and Jackson state that "[i]t is not clear that permitting the debtor to engage in a leveraged buyout.... is against the long-term interests of the creditors as a group." $"$ For this reason, they are reluctant to apply fraudulent conveyance law to LBOs.

For the purposes of their discourse, Baird and Jackson set up an opposing argument (the "straw argument") that would allow LBOs to be subject to fraudulent conveyance law. According to the straw argument, "the core principle of fraudulent conveyance law is that creditors should be able to set aside transfers by insolvent debtors that harm the creditors as a group." $" 18$ Baird and Jackson then show that the risk of harm is inherent in the debtorcreditor contract and that insulating creditors from all potential harm runs against the grain of contract law and stifles the public policy of encouraging entrepreneurs to find new ways to create wealth. ${ }^{59}$ Baird and Jackson find the straw argument overbroad as it would void as fraudulent many beneficial transactions simply be-

\footnotetext{
52. Id. at $852-55$.

53. Id. at 852 .

54. Id. at 831 .

55. Id. at $831-32$.

56. Id.

57. Id. at 833 .

58. Id.

59. Id. at 833-36.
} 
cause they made creditors as a group worse off. ${ }^{60}$ Also, the straw argument would give creditors a gratuitous insurance policy, protecting the creditors from all unwise investment decisions made by their debtor. ${ }^{61}$

The straw argument is not only overbroad, but it is also, Baird and Jackson believe, unnecessary, as creditors are free to bargain for contract provisions that prevent the debtor from engaging in an $\mathrm{LBO}^{62}$ Because contracting for fraudulent conveyance restrictions when the law of fraudulent conveyance is not generally applicable to LBOs is much easier than contracting out of fraudulent conveyance law when it is generally applicable to LBOs, Baird and Jackson argue that it is more efficient to exempt LBOs from fraudulent conveyance law. ${ }^{63}$ Moreover, Baird and Jackson maintain that in any case certain creditors who wish to ban their debtors from participating in LBOs are free to prohibit LBOs by contract. ${ }^{64}$

In the course of this discussion, Baird and Jackson reveal their central tenet: "The ambition of the law governing the debtorcreditor relationship, including fraudulent conveyance law, should [be to] provide all the parties with the type of contract that they would have agreed to if they had had the time and money to bargain over all aspects of their deal." ${ }^{25}$ Finding that creditors ideally would not have contracted for provisions banning LBOs as fraudulent conveyances, Baird and Jackson argue that LBOs should be outside the realm of fraudulent conveyance law as creditors can protect themselves with restrictive covenants in their loan contracts should they believe prohibiting LBOs is in their interests.

The fact that small trade creditors and nonconsensual creditors may be unable to engage in meaningful contract negotiations with many large corporations does not trouble Baird and Jackson because they argue that such creditors can easily rely on the larger creditors to contract for protections that benefit all the creditors of

60. Id. at 834 .

61. Id. at 839; see also Credit Managers Ass'n of Southern Cal. v. Federal Co., 629

F. Supp. 175, 181 (C.D. Cal. 1985) (noting insurance policy argument).

62. Baird \& Jackson, supra note 22, at 834-36.

63. Id.

64. Id.

65. Id. at $835-36$. 
the corporation..$^{66}$ Finding this contractual protection to be adequate, Baird and Jackson would argue that no LBO may be a fraudulent conveyance if it is an arm's-length transaction. ${ }^{67}$ They believe that a broader constructive provision as to LBOs might pick up more cases of fraudulent debtor behavior, but would do so only at the high cost of precluding many beneficial deals from occurring. ${ }^{68}$ They conclude that LBO transactions should not be voided as fraudulent conveyances if "the transferee parted with value when he entered into the transaction and ... the transaction was entered in the ordinary course." 169

\section{B. Policy Arguments for and Against LBO Exemption from Fraudulent Conveyance Law}

Baird and Jackson assert the following policy arguments in favor of exempting LBOs from fraudulent conveyance law: (1) applying fraudulent conveyance law to LBOs would be inefficient because not all creditors would bargain for the protections of fraudulent conveyance law if they had the choice and because those creditors who seek the protections from the effects of an LBO may contract for these protections; ${ }^{70}$ (2) applying fraudulent conveyance law to LBOs would provide creditors with an insurance policy by shifting the risk of loss from the creditors (with whom it usually is placed) to the debtor, ${ }^{71}$ and (3) applying fraudulent conveyance law to LBOs would greatly increase the risks of entering into otherwise useful and productive LBOs. ${ }^{2}$

On the other hand, as the Court of Appeals for the Third Circuit pointed out in Mellon Bank v. Metro Communications, ${ }^{3}$ unsecured creditors are very much at risk in an LBO. ${ }^{74}$ The prob-

66. Id. at 835,854 .

67. Id. at 854 .

68. Id. at $854-55$.

69. Id. at 855; see also In re EDC, Inc., 930 F.2d 1275, 1281 (7th Cir. 1991) (stating that "as long as business risks are in the open and are not forced on anyone, it is hard to see why when the risks materialize the persons hurt by them should be permitted to cry 'fraud!' ").

70. Baird \& Jackson, supra note 22, at 834-35.

71. Id. at $853-54$.

72. Id. at 853 .

73. 945 F.2d 635 (3d Cir. 1991), cert. denied sub nom. Committce of Unsccured Creditors v. Mellon Bank, 112 S. Ct. 1476 (1992).

74. Id. at 645; accord Moody v. Security Pac. Business Credit, 971 F.2d 1056, 1065, 1073 n.27 (3d Cir. 1992). 
lem is that small creditors lack substantial bargaining power and larger creditors may well have bargained for secured status rather than restrictive covenants banning LBOs. ${ }^{75}$ Thus, contrary to Baird and Jackson's assumption, this security interest benefits only the large creditors, such that the small creditors are unable to benefit from the stronger bargaining power of the large creditors. ${ }^{76}$ Furthermore, nonconsensual creditors, such as tort or tax claimants, are unable to bargain with the debtor at all. If the large creditors take security interests instead of restrictive covenants, the nonconsensual creditors are vulnerable, and never had any opportunity to bargain with the debtor. ${ }^{\pi}$

Furthermore, Baird and Jackson's contention that applying fraudulent conveyance law to LBOs would "shift" the risk of loss from the creditor to the debtor is a mischaracterization. The fraudulent conveyance laws had been well established before the first LBO ever occurred. LBO participants had no reason to believe that LBOs would be exempt from fraudulent conveyance laws. As the court in Crowthers McCall Pattern, Inc. v. Lewi ${ }^{78}$ stated, LBOs "can harm creditors in exactly the way fraudulent conveyance laws are designed to prevent. Accordingly, under the fraudulent conveyance laws, a lender is required to make a reasonable determination that the buy out is consistent with the rights of creditors before advancing funds." $"$ Baird and Jackson's arguments may convince a legislature to "shift" the risk of loss to the creditor by amending the fraudulent conveyance statutes to exempt LBOs; however, their policy arguments cannot be used to circumvent the clear language and purpose of the fraudulent conveyance statutes.

75. Kevin J. Liss, Note, Fraudulent Conveyance Law and Leveraged Buyouts, 87 COLUM. L. REV. 1491, 1510-13 (1987).

76. See id.

77. See United States v. Tabor Court Realty, 803 F.2d 1288, 1297 nn.2-3 (3d Cir. 1986), cert. denied sub nom. McClellan Realty Co. v. United States, 483 U.S. 1005 (1987); Liss, supra note 75 , at $1512-13$.

78. 129 B.R. 992 (S.D.N.Y. 1991).

79. Id. at 998 . 


\section{LBOs Will Not Be Exempted from Fraudulent Conveyance Because of the Plain Meaning of the Statute}

The main problem with Baird and Jackson's argument is that it is contrary to the unambiguous language of fraudulent conveyance statutes. ${ }^{80}$ The definition of "conveyance" in the UFCA and the definition of "transfer" in the Code and the UFTA are each broad enough to encompass almost all LBO transactions, ${ }^{81}$ and there are no express provisions that exempt LBOs from fraudulent conveyance law. In Ohio Corrugating Co. v. DPAC, Inc. (Ohio Corrugating II,${ }^{82}$ the court held that " $[t]$ he very essence of common law is its adaptability to unique situations and changing fact patterns. If the rights of creditors have been impaired, [there is] no reason to except LBOs from the operation of fraudulent conveyance law if the transfers otherwise fit within the statutory framework." ${ }^{83}$ In Mellon Bank v. Metro Communications, ${ }^{84}$ the

80. Seven states have no statute for constructively fraudulent conveyances. See ALASKA STAT. § 34.40.010 (1990); IND. CODE ANN. § 32-2-1-14 (Burns 1980); KAN. STAT. ANN. § 33-102 (1986); N.C. GEN. STAT. § 39-15 (1984); S.C. CODE ANN. § 27-23-10 (Law. Co-op. 1991); VT. STAT. ANN. tit. 9, \$2281 (1984); Richard O. Kummert, State Statutory Restrictions on Financial Distributions by Corporations to Shareholders, 59 WASH. L. REV. 185, 267 n.378 (1984) (noting that Iowa apparently has only a common law fraudulent conveyance rule). In these states, the application of fraudulent conveyance law to LBOs would be strictly a matter of common law. Although the same policy of creditor protection would apply in these states, a sympathetic judge would have much greater discretion to exempt LBOs from the scope of fraudulent conveyance law. In contrast, some of the non-uniform fraudulent conveyance statutes have provisions that are potentially more deleterious to LBOs than the UFTA, the UFCA, or $\S 548$. See, e.g., KY. REV. STAT. ANN. $§ 378.020$ (Baldwin 1989) (transfers for consideration deeined not valuable at law may be void as a fraudulent conveyance as to all creditors at the time of the transfer, regardless of the debtor's intent or financial condition); LA. CIV. CODE ANN. art. 2036 (West 1987) (creditors may void any transaction that "causes or increases" the debtor's insolvency); MISS. CODE ANN. § 15-3-3 (Supp. 1990) (transfers for consideration deemed not valuable at law may be void as a fraudulent conveyance as to all creditors at the time of the transfer, regardless of the debtor's intent or financial condition); MO. ANN. STAT. $\$ 428.040$ (Vernon 1992) (same); VA. CODE ANN. $\$ 55.81$ (Michie 1991) (same). But see .C-T of Va. v. Euroshoe Assocs., 762 F. Supp. 675 (W.D. Va. 1991) (LBO not a fraudulent conveyance under VA. CODE ANN. § 55.81), aff'd mem., 953 F.2d 637 (4th Cir. 1992).

81. See 11 U.S.C. $\$ 101(54)$ (Supp. II 1990); UNIF. FRAUDULENT CONVEYANCE ACT § 1, 7A U.L.A. 427, 430 (1985); UNIF. FRAUDULENT TRANSFER ACT § 1(12), 7A U.L.A. 639,645 (1985). For a discussion of judicial "collapsing" of what may appear as a series of discrete transactions, see infra subsection III(B)(1).

82. 91 B.R. 430 (Bankr. N.D. Ohio 1988).

83. Id. at 433; accord Kaiser Steel Corp. v. Jacobs (In re Kaiser Steel), 87 B.R. 154, 160-61 (Bankr. D. Colo. 1988).

84. 945 F.2d 635 (3d Cir. 1991), cert. denied sub nom. Committee of Unsecured 
Third Circuit stated that the definition of a "transfer" to which section 548 applies "is sufficiently broad to encompass a leveraged buyout transaction ...." The court also noted that "the statutory language provides no exception for the leveraged buyout transaction. $" 186$

After holding that LBOs are not exempt from Michigan's version of the UFCA, the court in Anderson Industries v. Anderson $^{87}$ stated that "[i]f this holding is too broad in the light of the present marketplace, it is the legislature, not the courts, that must narrow the statute." ${ }^{88}$ In sum, the courts can find no legal reason why the fraudulent conveyance laws should not be applied to LBOs, and they maintain that to grant such an exemption would be a usurpation of the legislative function and a violation of the doctrines of judicial restraint and separation of powers.

\section{A Novel Argument Based on the Recent Adherence of Many States to the UFTA}

In the twenty-nine states that have enacted the UFTA, ${ }^{89}$ Baird and Jackson's argument that the fraudulent conveyance statutes were never intended to apply to LBOs is even less convincing. Baird and Jackson argue that fraudulent conveyance law was never intended by the legislatures to be applied to LBOs because the "Statute of 13 Elizabeth" dates from 1571 and because the UFCA was promulgated in 1918, well before the advent of LBOs. In 1985, when their article was published, Baird and Jackson's argument made some sense because most states had

Creditors v. Mellon Bank, 112 S. Ct. 1476 (1992).

85. Id. at 646; accord United States v. Tabor Court Realty, 803 F.2d 1288, 1297 (3d Cir. 1986), cert. denied sub nom. McClellan Realty Co. v. United States, 483 U.S. 1005 (1987); Wieboldt Stores v. Schottenstein, 94 B.R. 488,499 (N.D. Ill. 1988).

86. Mellon Bank, 945 F.2d at 646; accord Ferrari v. Barclay's Business Credit (In re Morse Tool), 108 B.R. 389, 390-91 (Bankr. D. Mass. 1989); Vadnais Lumber Supply v. Byrne (In re Vadnais Lumber Supply), 100 B.R. 127, 134-35 (Bankr. D. Mass. 1989); Wieboldt, 94 B.R. at 499; Ohio Corrugating II, 91 B.R. at 433-34; Kaiser Steel, 87 B.R. at 161; Anderson Indus. v. Anderson (In re Anderson Indus.), 55 B.R. 922, 926 (Bankr. W.D. Mich. 1985); see also Queenan, supra note 31, at 24-25 (disagreeing with Baird \& Jackson's conclusion that LBOs are outside the coverage of the fraudulent conveyance statutes).

87. 55 B.R. 922 (Bankr. W.D. Mich. 1985).

88. Id. at 926; accord Tabor Court Realty, 803 F.2d at 1297; Ferrari, 108 B.R. at 391; Wieboldt, 94 B.R. at 500; Ohio Corrugating II, 91 B.R. at 434.

89. See supra note 28 . 
enacted the UFCA many years earlier. ${ }^{90}$ Although Congress had rewritten the constructive fraud provisions of the Code in 1978 without mentioning an LBO exemption, ${ }^{, 1}$ the LBO transaction was nascent at that time.

However, in each of the jurisdictions that have enacted the UFTA since 1985, this legislative intent argument would seem unavailing. These states enacted the UFTA after the issue of LBO exemption had been raised both in the caselaw and indeed in the Baird and Jackson article itself. ${ }^{92}$ In this context, it would seem that if the legislatures wished to exempt LBOs from their jurisdictions' fraudulent conveyance law, they would have drafted an express provision to that effect. Because no legislature has yet chosen to do so, ${ }^{93}$ it would seem that the legislatures that have enacted the UFTA have no difficulties with the cases that have uniformly refused to grant LBOs an exemption from fraudulent conveyance law. ${ }^{94}$

It is possible to argue that these legislators simply were signing onto the newly promulgated UFTA and were loath to change any provisions because it would interfere with the goal of achieving a uniform fraudulent conveyance law. Yet, states have not hesitated to alter provisions of the UFTA that they have felt needed amplification or were unwise. ${ }^{95}$ Therefore, it would be unpersuasive to argue that the ancient fraudulent conveyance statute in a jurisdiction was never meant by the legislature to be applied to LBOs when the statute in that jurisdiction was enacted in the late 1980s after the issue of LBO exemption was already raised.

Strangely, this argument has not been mentioned in any cases or commentaries to date. In Kupetz $v$. Continental Illinois National Bank and Trust Co. $(C I N B),{ }^{96}$ the court did not have the ques-

90. Unif. Fraudulent CONVEyance Act, 7A U.L.A. 427 (1985) (table of jurisdictions in which the UFCA has been adopted).

91. See Bankruptcy Act of 1978, Pub. L. No. 95-578, 92 Stat. 2549, 2600-01 (codified at 11 U.S.C. $\& 548$ (1988)).

92. See UNIF. Fraudulent TRANSFer ACT, 7A U.L.A. 133 (Supp. 1992) (table of jurisdictions in which the UFTA has been adopted).

93. Id. at 133-34.

94. See supra cases cited in note 49.

95. See UNif. Fraudulent Transfer Act, 7A U.L.A. 133-34 (Supp. 1992) (general statutory notes); Richard F. Dole, Jr. \& Vernon Teofan, The Nonuniform Texas "Uniform" Fraudulent Transfer Act, 42 SW. L.J. 1029 (1989).

96. 77 B.R. 754 (C.D. Cal. 1987), affd sub nom. Kupetz v. Wolf, 845 F.2d 842 (9th 
tion of LBO exemption before it; however, the court mentioned in dicta that it was quite reluctant to apply fraudulent conveyance law to an LBO. The court stated that it was loath "to apply 'a law with its origins in 16th Century England to a financial transaction which did not exist on a large scale until the 1980s." "97 The court's reluctance might have been justified, as it was considering the application of California's version of the UFCA, a statute enacted in $1939 .{ }^{98}$ Still, it is strange that the court failed to mention that the California legislature had enacted a new fraudulent conveyance statute (its version of the UFTA) just one year before the opinion in CINB was written. ${ }^{99}$ Despite the fact that the issue of LBO exemption had been raised by 1986 and that no court had found LBOs to be exempt, the California legislature did not enact an LBO exemption provision in its version of the UFTA. ${ }^{100}$

In Kaiser Steel v. Jacobs (In re Kaiser Steel), ${ }^{101}$ although the issue of LBO exemption from the fraudulent conveyance law of California was squarely before the court, the court still failed to hit upon the legislative ratification argument. In Kaiser, the investment banking firm of Goldman Sachs was a defendant in a fraudulent conveyance action arising out of an LBO in which it took part. ${ }^{102}$ Goldman argued that the California UFCA was not applicable to LBOs for the following reasons: "the UFCA is derivative of sixteenth century English law and ... the UFCA itself was drafted in 1918, long before the advent of the modern LBO."103

The court responded by pointing out that it is a fundamental facet of Anglo-American common law that old laws are applied to novel and dynamic circumstances. ${ }^{104}$ The court's logic is sound and its result is correct; however, it does seem curious that on the very same page of its opinion, the court refers in a footnote to the newly enacted UFTA without mentioning the legislature's recent consideration of the issue. ${ }^{105}$ This point in the opinion

Cir. 1988).

97. 77 B.R. at 759 (quoting Credit Managers Ass'n of Southern Cal. v. Federal Co., 629 F. Supp. 175, 179 (C.D. Cal. 1985)).

98. See UNIF. FRAUdUlent CONVEYANCE ACT, 7A U.L.A. at 427.

99. See UNIF. Fraudulent TransFer ACT, 7A U.L.A. at 639.

100. 'Id.

101. 87 B.R. 154, 160 61 (Bankr. D. Colo. 1988).

102. Id. at $155-56$.

103. Id. at 160 (citation omitted).

104. Id.

105. Id. at 160 n.*. 
would seem to have been an ideal place to indicate to investment banking firms such as Goldman Sachs that the UFTA was enacted in 1986 with no indication from the California legislature that LBOs should be exempt from fraudulent conveyance law. As adjudication of cases under the UFTA begins, perhaps in the future this argument of legislative acquiescence and ratification will be raised in opposition to an argument for LBO exemption.

\section{A CAUTIOUS ANALYSIS OF LBOS UNDER FRAUDULENT CONVEYANCE LAW}

Baird and Jackson make several presumptions in their article that are not necessarily warranted: first, that the only argument against exempting LBOs from fraudulent conveyance law is the straw argument; ${ }^{106}$ second, that applying fraudulent conveyance law to LBOs would insulate creditors from all risks; and third, that determining when a debtor is "insolvent" or supported by "unreasonably small capital" is a highly problematic undertak$\mathrm{mg}^{107}$ and that judges will inexorably be drawn into the use of hindsight in making their valuations of the LBO target's business. ${ }^{108}$

First, Baird and Jackson assume that the only argument against exempting LBOs from fraudulent conveyance law is the straw argument. Baird and Jackson do not address the fact that LBOs fall within the plain meaning of fraudulent conveyance statutes. Because no legislature has exempted LBOs from fraudulent conveyance law, a judge would have to usurp the power of the legislature in order to grant LBOs such an exemption. This separation of powers argument precludes judges from exempting LBOs from fraudulent conveyance law, yet Baird and Jackson never discuss this issue.

Second, Baird and Jackson's insurance policy argument assumes that fraudulent conveyance law would protect creditors from all risk of loss due to bad deals entered into by their debtor. The problem with this insurance policy notion is that fraudulent conveyance statutes do not shield creditors from all bad deals, but rather, they protect creditors from bad deals that lack sufficient consideration and leave the company either insolvent or with

106. Baird \& Jackson, supra note 22, at 832-34; supra text accompanying notes 58-61.

107. Id. at 838,851 .

108. Id. at $841-42$. 
"unreasonably small capital." Because fraudulent conveyance statutes do not insulate creditors from all or even most corporate risks, the insurance policy argument only confuses the issue. Nobody argues that creditors should be free from all risk of loss; the issue is whether the fraudulent conveyance laws can provide meaningful standards of behavior in the complex context of an LBO.

Third, Baird and Jackson's assumption that bankruptcy judges are unable to make the complex valuations necessary to apply fraudulent conveyance statutes to LBOs is unwarranted. Judges must make difficult valuations of business entities in many areas of bankruptcy law. ${ }^{109}$ As challenging as these valuations may be, they certainly are not impossible to manage. It should not be too difficult for LBO participants to justify valuations of the target company's solvency and adequate capitalization, because it is likely that these players will compile detailed financial analyses of the LBO on their own. Forcing LBO participants to act responsibly and with reasonable justification is a worthwhile public policy goal that justifies applying fraudulent conveyance law to LBOs. As the Crowthers McCall court stated, "under the fraudulent conveyance laws, a lender is required to make a reasonable determination that the buy out is consistent with the rights of creditors before advancing funds." 110

Baird and Jackson are quite right when they assert that "[e]xtending fraudulent conveyance law beyond preventing sham transactions and gratuitous transfers by insolvents is a step that should be taken only with caution." ${ }^{111}$ Nonetheless, they use caution to explain why most LBOs should be exempt from fraudulent conveyance law, in defiance of the plain meaning of the statute. Instead of this tack, a cautious and thoughtful approach should be used to develop appropriate fraudulent conveyance standards for LBOs in order to execute the command of existing statutes. If these standards become too burdensome for the business community, business leaders should lobby the legislatures for statutory

109. See, e.g., 11 U.S.C. $\S 101(32)$ (Supp. II 1990) (valuation of entity's property in order to determine solvency); 11 U.S.C. $\S 361$ (1988) (valuation of interest in property for adequate protection purposes); $i d$. $\S 506(\mathrm{a})$ (valuation of collateral required in order to determine extent of creditor's secured status); id. $\S 547(\mathrm{c})(5)$ (valuation of collateral in applying the "improvement in position test," often in the context of inventory and receivables financing).

110. Crowthers McCall Pattern, Inc. v. Lewis, 129 B.R. 992, 998 (S.D.N.Y. 1991).

111. Baird \& Jackson, supra note 22 , at 840 . 
relief. This Part examines how the fraudulent conveyance statutes may be pragmatically applied in the complex context of an LBO.

\section{A. Intentionally Fraudulent Conveyances}

Because it is much more difficult to prove an actual intent to defraud in an LBO transaction, fraudulent conveyance plaintiffs in LBO lawsuits usually focus on the constructive fraud provisions of the fraudulent conveyance statutes. ${ }^{112}$ Nevertheless, these plaintiffs invariably plead intentional fraud as well.

The distinction between the intentional fraud and constructive fraud provisions can become blurred in the context of an LBO transaction. This confusion is largely due to the fact that, although the constructive fraud provisions constitute separate causes of action from the intentional fraud provisions, the elements of a constructively fraudulent conveyance can also be used to prove intentional fraud under the "badges of fraud" doctrine. ${ }^{113}$ With these "badges of fraud" separated out as distinct causes of action, the fraudulent conveyance statutes contain a degree of redundancy.

The leading case on LBOs as intentional fraudulent conveyances is United States v. Tabor Court Realty, ${ }^{114}$ decided by the Third Circuit in 1986. A multitude of transfers involving coal lands, the Teamsters Union, and Jimmy Hoffa, Jr. culminated in an LBO that was executed under highly suspicious circumstances with various shell corporations and a target that was experiencing severe economic difficulty. ${ }^{115}$ The district court had invalidated several mortgages involved in the transaction as fraudulent conveyances under both the intentional fraud and constructive fraud provisions of Pennsylvania's UFCA. ${ }^{116}$

The Third Circuit affirmed all of the main holdings of the district court in the first application of fraudulent conveyance law to an LBO. ${ }^{117}$ The court held that "[u]nder Pennsylvania law, an

112. Moody v. Security Pac. Business Credit, 971 F.2d 1056, 1064 (3d Cir. 1992).

113. See supra note 23 and accompanying text; infra note 123 and accompanying text.

114. 803 F.2d 1288 (3d Cir. 1986), cert. denied sub nom. McClellan Realty Co. v. United States, 483 U.S. 1005 (1987).

115. Id. at 1291-94.

116. United States v. Gleneagles Inv. Co. (Gleneagles I), 565 F. Supp. 556, 585-86 (M.D. Pa. 1983), affd sub nom. United States v. Tabor Court Realty, 803 F.2d 1288 (3d Cir. 1986), cert. denied sub nom. McClellan Realty Co. v. United States, 483 U.S. 1005 (1987).

117. For a detailed analysis of the Gleneagles cases, see David A. Murdoch et al, 
intent to hinder, delay, or defraud creditors may be inferred from transfers in which consideration is lacking and where the transferer [sic] and transferee have knowledge of the claims of creditors and know that the creditors cannot be paid."118 Knowledge that the target is incurring debts beyond its ability to pay can be inferred from knowledge that the transaction renders the target insolvent or with "unreasonably small capital."119 The Third Circuit held that parties to an LBO can be deemed to have intended the natural consequences of their actions. ${ }^{120}$ Therefore, if LBO participants know that they are engaging in a transaction that renders the target insolvent or leaves it with unreasonably small capital, then these participants may be deemed to have intentionally defrauded their creditors. ${ }^{121}$

The major difference between the intentional and constructive fraud provisions is the plaintiff's burden of proof, which is "clear and convincing evidence" under intentional fraud provisions and "preponderance of the evidence" under constructive fraud provisions. ${ }^{122}$ Intentional fraud can also be inferred from various "badges of fraud" other than those contained in the constructive fraud provisions. ${ }^{123}$ Because fraudulent conveyance plaintiffs can get the same remedy with a lesser burden of proof under the

Leveraged Buyouts and Fraudulent Transfers: Life After Gleneagles, 43 Bus. LAw. 1 (1987).

118. Tabor Court Realty, 803 F.2d at 1304.

119. Queenan, supra note 31 , at 7 n.37 (citing United States v. 58th St. Plaza Theatre, 287 F. Supp. 475, 498 (S.D.N.Y. 1968)).

120. Tabor Court Realty, 803 F.2d at 1305 (citing In re Process-Manz Press, 236 F. Supp. 333, 347 (N.D. Ill. 1964), rev'd on other grounds, 369 F.2d 513 (7th Cir. 1966), cert. denied, 386 U.S. 957 (1967)).

121. Id. at 1304-05; Process-Manz, 236 F. Supp. at 347.

122. See Gleneagles $I, 565 \mathrm{~F}$. Supp. at 580 (proof of actual intent requires clear and convincing evidence); Moody v. Security Pac. Business Credit, 127 B.R. 958, 990 (W.D. Pa. 1991), affd, 971 F.2d 1056 (3d Cir. 1992). Note that the burdens of proof can vary from state to state. For example, in Ohio and Pennsylvania, the burden of proof by preponderance of evidence shifts to the defendant in constructive fraud cases after the plaintiff has proven lack of sufficient consideration, see Ohio Corrugating v. Security Pac. Business Credit (In re Ohio Corrugating) (Ohio Corrugating I), 70 B.R. 920, 927 (Bankr. N.D. Ohio 1987); Gleneagles I, 565 F. Supp. at 577, but in Massachusetts the burden always remains on the plaintiff, see Murphy v. Meritor Sav. Bank (In re O'Day Corp.), 126 B.R. 370, 390 (Bankr. D. Mass. 1991).

123. See Moody, 127 B.R. at 990; Wieboldt Stores v. Schottenstein, 94 B.R. 488, 504 (N.D. Ill. 1988); 4 COLLIER ON BANKRUPTCY, supra note 26, II 548.02[5], at 548-39 to 548-49; see also UNIF. FRAUDULENT TRANSFER ACT § 4(b), 7A U.L.A. 639, 653 (1985) (laundry list of badges of fraud from which an actual intent to defraud may be inferred). 
constructive fraud provisions, these plaintiffs will concentrate their energies on the constructive fraud causes of action unless they have reason to believe that blatant fraud occurred in the LBO.

\section{B. Sufficient Consideration Analysis}

In determining whether sufficient consideration has been given, the overall effect of the LBO on the target corporation is considered, rather than the effect of each discrete transaction. This mode of analysis is called "collapsing" the LBO transactions. "Collapsing" is important because it prevents LBO lenders and former shareholders of the target corporation from taking advantage of the "savings clauses" for good-faith purchasers in the fraudulent conveyance statutes. ${ }^{124}$ On paper, LBO lenders may have received value for their security interests, or they may not have received assets directly from the LBO target. ${ }^{125}$ Once the LBO transactions are collapsed, however, these paper buffers disappear, and the LBO participants are unable to take advantage of the savings clauses in the fraudulent conveyance statutes. This Part shows that once the LBO transactions are collapsed, sufficient consideration is unlikely to be found unless concrete indirect benefits accrue for the target corporation.

1. Direct Benefits as Sufficient Consideration. As mentioned in Part I, the term "sufficient consideration" will be used to refer to the degree of consideration required under the UFCA, UFTA, and section 548 for a transaction not to be a constructively fraudulent conveyance. ${ }^{126}$ Unlike contract law, fraudulent conveyance law measures the adequacy of consideration involved in the transactions to which it is applied. ${ }^{127}$ Furthermore, because the purpose of fraudulent conveyance law is to protect creditors from unwarranted depletion of the debtor's assets, the sufficiency of the

124. These "savings clauses" are found in 11 U.S.C. $\S \S 548(\mathrm{c}), 550(\mathrm{~b})$ (1988); UNIF. Fraudulent ConveYance ACT $\$$ 9,7A U.L.A. at 577-78; and UNIF. Fraudulent TRANSFER ACT $\S 8,7 A$ U.L.A. at 662-63. Under these savings clauses, an immediate good faith transferee would be protected to the extent that he gave value to the debtor, and a subsequent good faith transferee also would be shielded from liability if he had no knowledge of the voidability of the transfer. See Cieri et al., supra note 20, at 367.

125. See Wieboldt, 94 B.R. at 500; Cieri et al., supra note 20, at 367.

126. See supra note 35 .

127. See Vadnais Lumber Supply v. Byrne (In re Vadnais Lumber Supply), 100 B.R. 127, 136 (Bankr. D. Mass. 1989); Queenan, supra note 31, at 8. 
consideration is viewed from the perspective of the LBO target's creditors. ${ }^{128}$ As the court stated in Ohio Corrugating $I,{ }^{129}$ "[a]n analysis of an allegedly fraudulent transfer must be directed at what the Debtor surrendered and what the Debtor received, irrespective of what any third party may have gained or lost. The rationale of the fraudulent transfer provision of the Code is to preserve the assets of the estate." 130

There are a variety of structures that can be used in an LBO so that the target corporation does not directly borrow its own purchase price for the benefit of its buyers. ${ }^{131}$ Nonetheless, in determining the sufficiency of consideration, courts will look past the formal structure of the LBO in order to ascertain the overall gains and losses that the target corporation has realized once the LBO is complete. ${ }^{132}$ In this way, courts collapse the series of LBO

128. Crowthers MeCall Pattern, Inc. v. Lewis, 129 B.R. 992, 998 (S.D.N.Y. 1991); Murphy v. Meritor Sav. Bank (In re O'Day Corp.), 126 B.R. 370, 390 (Bankr. D. Mass. 1991); United States v. Gleneagles Inv. Co. (Gleneagles I), 565 F. Supp. 556, 585-86 (M.D. Pa. 1983), affd sub nom. United States v. Tabor Court Realty, 803 F.2d 1288 (3d Cir. 1986), cert. denied sub nom. McClellan Realty Co. v. United States, 483 U.S. 1005 (1987).

129. Ohio Corrugating v. Security Pac. Business Credit (In re Ohio Corrugating), 70 B.R. 920 (Bankr. N.D. Ohio 1987).

130. Id. at 927.

131. See generally David G. Carlson, Leveraged Buyouts in Bankruptcy, 20 GA. L. REV. 73, $80-83$ (1985) (discussing the following structures: 1) target's stock pledged to LBO lenders; 2) upstream secured guarantee by target of shell corporation's acquisition debt; 3) pledge of all of target's assets following merger of shell with target; 4) secured loan directly from lender to target, target redeems shares of those not participating in LBO; 5) direct loan to target which reloans funds to shell corporation; and 6) upstreain guarantees by target subsidiaries); Cieri et al., supra note 20 , at $356-58$ (discussing the following structures: 1) stock purchase LBO, financed by third-party lender, secured by pledge of target stock; 2) stock purchase LBO, financed by third-party lender, direct loan to target, secured by a pledge of target assets; 3) stock or asset purchase LBO, financed by seller or third-party lender, payment of all existing creditors at time of LBO; and 4) asset purchase LBO, third-party lender, pledge of target assets, target liquidates). It should be noted here that if the LBO lenders only take security in the LBO target's equity, there is no sufficiency of consideration problem, and no fraudulent conveyance concerns are raised. See id. at 356 (citing Carlson, supra, at 81). However, few LBO lenders can be expected to agree to such an equity position.

132. See United States v. Tabor Court Realty, 803 F.2d 1288, 1302-03 (3d Cir. 1986), cert. denied sub nom. McClellan Realty Co. v. United States, 483 U.S. 1005 (1987); Moody v. Security Pac. Business Credit, 127 B.R. 958, 992 (W.D. Pa. 1991), affd, 971 F.2d 1056 (3d Cir. 1992); Murphy, 126 B.R. at 394; Wieboldt Stores v. Schottenstein, 94 B.R. 488, 502-04 (N.D. Ill. 1988); Gleneagles I, 565 F. Supp. at 574-75. Even Baird and Jackson admit that courts will do this. See Baird \& Jackson, supra note 22, at 851 . 
transactions into one aggregate in order to ascertain the cumulative effect upon the target corporation.

The court in Wieboldt Stores v. Schottenstein ${ }^{133}$ misapplied the collapsibility doctrine. ${ }^{134}$ Instead of treating collapsibility as a straightforward doctrine of substance-over-form, the Wieboldt court manufactured a knowledge requirement for collapsibility. ${ }^{135}$ Finding that defendants should have the LBO transactions collapsed as to them only if they knew of the totality of the structure of the transaction, ${ }^{136}$ the court collapsed the transaction as to the LBO lenders and the insider stockholders because it found that they had had the requisite knowledge. On the other hand, the court refused to collapse the transaction as to the target corporation's public shareholders, curiously finding that these shareholders lacked the requisite knowledge. ${ }^{137}$

The Wieboldt analysis for collapsing the LBO transaction is flawed. The court went out of its way to relieve the public stockholders of liability, and as a result the court created bad law on LBO collapsibility. The public shareholders in Wieboldt almost certainly knew that the tender offer was being financed through an LBO, either through disclosures made in the tender offer they had received or through information in the media. These shareholders do not deserve much sympathy because they received a significant windfall by being cashed out of a company that was on the verge of bankruptcy. Therefore, there is no reason to cloud the sufficiency of consideration analysis with a "knowledge or intent" requirement in order to relieve the "innocent" public shareholders of liability.

The Wieboldt court's creation of a knowledge requirement for collapsibility is unsound and unwarranted: A knowledge requirement for collapsing LBO transactions is required neither by fraudulent conveyance statutes nor by logic. The most sensible approach is to collapse LBO transactions as a matter of course. As Baird and Jackson themselves state: "Courts, however, typically

133. 94 B.R. 488 (N.D. Ill. 1988).

134. See id. at 502-04. This confusing analysis may have been due in part to the circumstances of the opinion-a denial of a motion to dismiss by some of the defendants in which the court seems to engage in the practice of using stern language in an attempt to scare the defendants into a settlement.

135. See id.

136. See id.

137. See id. 
have had no difficulty construing such a segmented transaction as one deal. Courts will not allow the labels that interested parties place on their own transactions to control the rights of third parties." ${ }^{138}$

This succinct rationale is all that should be necessary for courts to collapse an LBO transaction. The Wieboldt court's use of a knowledge requirement only confuses the analysis and risks venturing into the area of intentional fraud. In Vadnais Lumber Supply v. Byrne (In re Vadnais Lumber Supply), ${ }^{139}$ the court simply stated that "[i]n applying the test [of sufficiency of consideration], we must examine all aspects of the transaction in order to measure carefully the value of all of its benefits and burdens to the Debtor, direct or indirect." ${ }^{\text {140 }}$ The court did not engage in a lengthy analysis of the degree of the parties' "knowledge or intent"; rather, it simply stated that the transaction is to be analyzed so as to measure the total effect of the LBO upon the target, ignoring any formalistic labels used by the parties. The approach taken in Vadnais Lumber is the most rational approach to collapsibility in the context of a sufficiency of consideration analysis.

2. Indirect Benefits as Sufficient Consideration. Because courts will collapse an LBO transaction and examine its overall effect on the target, almost every LBO is likely to fail the sufficiency of consideration test if the only measure of consideration is the direct benefit to the target. In an attempt to meet the yardstick of sufficient consideration, parties have argued that various aspects of the LBO transaction can give the target corporation indirect benefits. ${ }^{141}$ An inquiry into the realization of indirect benefits is a legitimate aspect of fraudulent conveyance analysis. ${ }^{142}$ Nonetheless, it is not clear to what extent indirect benefits may be realized in the context of an LBO. Some indirect benefits that may accrue to a corporation through an LBO are: better management, money saved by going private and no longer having to comply with federal securities laws applicable to public companies, synergies, and intercorporate guarantees.

138. Baird \& Jackson, supra note 22 , at 851 .

139. 100 B.R. 127 (Bankr. D. Mass. 1989).

140. Id. at 136 .

141. See infra notes $143-53$ and accompanying text.

142. Rubin v. Manufacturers Hanover Trust Co., 661 F.2d 979, 991-92 (2d Cir. 1981). 
Although more efficient management has been asserted to be an indirect benefit that should be counted as consideration in an $\mathrm{LBO},{ }^{143}$ the cases to date have all held that better management should not be counted as consideration because it is a speculative benefit that cannot easily be calculated in monetary terms. ${ }^{144}$ These holdings highlight the paramount concern courts generally have had when scrutinizing possible indirect benefits-that the benefits have a measurable financial value. ${ }^{145}$

By going private, a corporation can save the expenses of complying with the strict securities laws governing publicly held firms. ${ }^{145}$ No court has addressed the issue of whether these savings may serve as indirect benefits in a sufficiency of consideration analysis of an LBO under fraudulent conveyance law. Although these savings are perhaps quantifiable, they may be too speculative, or courts may feel that they are de minimis, especially in the context of a transaction where the professional fees involved can be in the tens of millions of dollars. ${ }^{147}$

Most LBOs are simply a rearrangement of the capital structure of a single operating company, having no potential for synergy; however, when one operating company acquires another operating company through the mechanism of an LBO, potential synergies may exist that can be factored into a sufficiency of consideration analysis. ${ }^{148}$ As with any indirect benefit, the synergies

143. See Baird \& Jackson, supra note 22, at 853.

144. Moody v. Security Pac. Business Credit, 127 B.R. 958, 993 (W.D. Pa. 1991), affd, 971 F.2d 1056 (3d Cir. 1992); Credit Managers Ass'n of Southern Cal. v. Federal Co., 629 F. Supp. 175, 182 (C.D. Cal. 1985); United States v. Gleneagles Inv. Co. (Gleneagles I), 565 F. Supp. 556, 576 (M.D. Pa. 1983), aff'd sub nom. United States v. Tabor Court Realty, 803 F.2d 1288 (3d Cir. 1986), cert. denied sub nom. McClellan Realty Co. v. United States, 483 U.S. 1005 (1987); see also Queenan, supra note 31, at 12 (noting that enhanced management does not constitute adequate consideration because it has no identifiable monetary value). But cf. C-T of Va. v. Euroshoe Assocs., 762 F. Supp. 675, 678-79 (W.D. Va. 1991) (new management is an element to be considered under "consideration deemed valuable at law" test of non-uniform Virginia fraudulent conveyance statute), aff'd mem., 953 F.2d 637 (4th Cir. 1992).

145. See Credit Managers, 629 F. Supp. at 182; Cieri et al., supra note 20, at 354-55; Liss, supra note 75 , at 1501 .

146. See Liss, supra note 75 , at 1501 .

147. See id. at 1502.

148. See Mellon Bank v. Metro Communications, 945 F.2d 635, 647-48 (3d Cir. 1991) (holding that synergies created in an acquisition by LBO should be measured and included as consideration in the sufficiency of consideration calculus of fraudulent conveyance law), cert. denied sub nom. Committee of Unsecured Creditors v. Mellon Bank, 112 S. Ct. 1476 (1992). 
must be definite and measurable as of the time of the LBO. ${ }^{149}$ Determining the value of such potential synergies requires detailed financial analysis and projections. As in the solvency and "unreasonably small capital" analyses discussed below, ${ }^{150}$ courts face the difficult task of scrutinizing these projections and determining if the expectations of the parties were reasonable as of the time of the transaction. In the unusual LBO in which synergies may be realized, the LBO participants may be able to meet the sufficiency of consideration requirement by relying on their reasonable financial projections just as they are able to rely on these data in the typical LBO to prove solvency and adequate capitalization.

In the atypical LBO discussed above, the target corporation may also be able to claim as valuable consideration a guarantee made by the acquiring corporation. The law of intercorporate guarantees is still evolving in the context of fraudulent conveyance law. ${ }^{151}$ Nevertheless, if the acquiring corporation has enough equity to make the guarantee valuable, then it can include this guarantee in determining the sufficiency of the consideration in the LBO. ${ }^{152}$ In analyzing such guarantees, courts will undertake a careful analysis of the economic value flowing to the debtor as a result of the guarantee. ${ }^{153}$

Unless the LBO is an unusual one in which synergies are created or valuable guarantees are given, courts are not likely to find any significant indirect consideration. Therefore, LBOs will usually not be able to satisfy the sufficiency of consideration requirement. ${ }^{154}$ Most LBO participants defending fraudulent con-

149. See Rubin v. Manufacturers Hanover Trust, 661 F.2d 979, 992-93 (2d Cir. 1981) (holding that the trial court was in error because it did not attempt to quantify the indirect benefits).

150. See infra text accompanying notes 185-204.

151. For more detailed treatments of intercorporate guarantees, see Kenneth J. Carl, Fraudulent Transfer Attacks on Guaranties in Banknuptcy, 60 AM. BANKR. L.J. 109 (1986); William H. Coquillette, Guaranty of and Security for the Debt of a Parent Corporation by a Subsidiary Corporation, 30 CASE W. RES. L. REV. 433 (1980); Robert J. Rosenberg, Intercorporate Guaranties and the Law of Fraudulent Conveyances: Lender Beware, 125 U. PA. L. REV. 235 (1976); Scott F. Norberg, Comment, Avoidability of Intercorporate Guarantees Under Sections 548(a)(2) and 544(b) of the Bankruptcy Code, 64 N.C. L. REV. 1099 (1986).

152. See Mellon Bank, 945 F.2d at 647-48.

153. See id. at 647-650; Rubin, 661 F.2d at 991-93; Garrett v. Falkner, 23 B.R. 28 (Bankr. N.D. Ala. 1982); Queenan, supra note 31, at 11-12.

154. See Cieri et al., supra note 20, at 354-55; Queenan, supra note 31 , at 13; Liss, supra note 75 , at 1497 . 
veyance actions will have to rely on the target's solvency and adequate capitalization in order to avoid liability.

\section{Solvency Analysis}

There are many areas of bankruptcy law that require courts to make valuations. ${ }^{155}$ If courts permit valuations to be performed using reckless, inaccurate, or unrealistic methods, then not only will an injustice be worked upon the particular parties involved in the case, but the increase in uncertainty in bankruptcy law will decrease overall economic efficiency. This is true with regard to any valuation that a bankruptcy court performs. The valuations of companies and complex corporate transactions is rarely a simple task; accordingly, such valuations must always be performed in a careful and thorough manner. Nonetheless, the difficulty of these valuations should highlight the need for elaborate and intelligent standards rather than the inability of judges to engage in them. Rather than refuse to apply fraudulent conveyance law to LBOs (as Baird and Jackson urge), judges should perform valuations of the debtor with due consideration for the uncertainty and imprecision involved in financial analyses.

Section 2(1) of the UFCA states that "[a] person is insolvent when the present fair salable value of his assets is less than the amount that will be required to pay his probable liability on his existing debts as they become absolute and matured." 156 Unfortunately, solvency analysis under this provision has not been uniform among the courts. Although this standard of insolvency compares assets against liabilities, indicating insolvency in the bankruptcy sense, the use of the terms "present" and "pay ... debts as they become absolute and matured" has led courts into an analysis that seems to drift into the realm of insolvency in the equity sense. ${ }^{157}$

155. For some examples, see supra note 109.

156. UNIF. FRAUDULENT CONVEYANCE ACT \& 2(1), 7A U.L.A. 427, 442 (1985).

157. See Queenan, supra note 31, at 13-14; see also United States v. Tabor Court Realty, 803 F.2d 1288, 1303 (3d Cir. 1986) (holding that substantial coal lands have no value for purposes of solvency analysis because this value could not be realized by the debtor in time to pay off debts as they became due), cert. denied sub nom. McClellan Realty Co. v. United States, 483 U.S. 1005 (1987); accord Wieboldt Stores v. Schottenstein, 94 B.R. 488, 505 (N.D. IIl. 1988) ("Assets may be reduced by the value of the assets that cannot be readily liquidated."); Corbin v. Franklin Nat'l Bank (In re Franklin Nat'l Bank), 2 B.R. 687, 711-12 (Bankr. E.D.N.Y. 1979), aff'd without opinion, 633 F.2d 203 (2d Cir. 1980); Glenmore Distilleries Co. v. Seideman, 267 F. Supp. 915, 918 (E.D.N.Y. 1967). 
Despite this inclination, most courts have utilized a bankruptcy approach to insolvency analysis. ${ }^{158}$ In order to eliminate this confusion, the UFTA deletes the troublesome language of the UFCA, and defines insolvency as a situation where "the sum of the debtor's debts is greater than all of the debtor's assets at a fair valuation."159 This definition of insolvency is essentially the same as the Bankruptcy Code's definition. ${ }^{160}$

In valuing the company, book values (based on Generally Accepted Accounting Principles) are not controlling. ${ }^{161}$ Because book values are conservative and because LBOS are premised on the existence of hidden value not recognized in book values, using book values to measure solvency in LBOs would render almost every LBO target insolvent, effectively voiding every LBO challenged in court as a fraudulent conveyance. Almost every court that has addressed the issue has stated that going concern values should normally be used rather than book values or liquidation values. ${ }^{162}$ Nonetheless, due to the troublesome language of section 2(1) of the UFCA, two distinct valuation approaches have developed. This Section first explores the "piecemeal approach" to solvency valuation, which attempts to find going concern values for each item on the LBO target's balance sheet. After examining the shortcomings of the "piecemeal approach," this Section explores the virtues of the "holistic approach" to solvency valuation. The "holistic approach," which would find most LBO targets to be solvent, focuses on whether or not the target has been left with "unreasonably small capital."

1. The Piecemeal Approach to Solvency Valuation. Under the piecemeal approach, the court uses the book values of the

158. See, e.g., Seligson v. New York Produce Exch., 394 F. Supp. 125, 129 (S.D.N.Y. 1975).

159. UNIF. FrauduleNt TRANSFER ACT § 2(a), 7A U.L.A. 639, 648 (1985).

160. See 11 U.S.C. § 101(32) (Supp. II 1990).

161. Murphy v. Meritor Sav. Bank (In re O’Day Corp.), 126 B.R. 370, 398 (Bankr. D. Mass. 1991); Ohio Corrugating Co. v. DPAC, Inc. (In re Ohio Corrugating Co.) (Ohio Corrugating II), 91 B.R. 430, 438 (Bankr. N.D. Ohio 1988).

162. Moody v. Security Pac. Business Credit, 127 B.R. 958, 995 (W.D. Pa. 1991), affd, 971 F.2d 1056, 1067 (3d Cir. 1992); Murphy, 126 B.R. at 398-99; Vadnais Lumber Supply v. Byrne (In re Vadnais Lumber Supply), 100 B.R. 127, 131 (Bankr. D. Mass. 1989); Ohio Corrugating II, 91 B.R. at 437-38; see also 2 COLLIER ON BANKRUPTCY, supra note $26, \S 101.32[5]$. 
firm as a starting point. ${ }^{163}$ It then creates a "reconstituted balance sheet," which supposedly represents the "going concern value" of each asset and liability at the time of the LBO. ${ }^{164}$ If the reconstituted balance sheet indicates that liabilities exceed assets either immediately before or immediately after an LBO, then the company is found insolvent. Courts have struggled to perform the paradoxical task of reconstituting a balance sheet on an item-by-item basis with "going concern values."

In Ohio Corrugating $I I,{ }^{166}$ although explicitly rejecting a going concern valuation for machinery and equipment because the court felt that the figures were not "reliable," the court valued inventory based on its "going concern" value ${ }^{167}$ Furthermore, the court was inclined to value the company's real estate at book value, ${ }^{168}$ despite the fact that book values often significantly undervalue real estate (because book value is the price paid for the real estate regardless of how long ago it was acquired).

The validity of the court's analysis in Ohio Corrugating II is questionable. The court quite strangely stated that the debtor was solvent despite a net worth of negative $\$ 700,000$ based upon the court's reconstituted balance sheet. ${ }^{169}$ Admitting that it was not confident in its own figures, the court stated that the corporation was solvent despite its negative net worth because of its demonstrated ability to pay off its debts as they had come due for ten months after the LBO. ${ }^{170}$ Not only does this reveal a poor valuation method on the court's part, but it also indicates how the language of section 2(1) of the UFCA can draw courts into an equitable insolvency mode.

163. E.g., Murphy, 126 B.R. at 398.

164. See Moody, 127 B.R. at 978-83; Murphy, 126 B.R. at 403; Ohio Corrugating II, 91 B.R. at $436-40$.

165. See Moody, 127 B.R. at 978-79, 983 (employing item-by-item valuation in which court finds present value of receivables to be their value as collected in the future).

166. Ohio Corrugating Co. v. DPAC, Inc. (In re Ohio Corrugating Co.), 91 B.R. 430 (Bankr. N.D. Ohio 1988).

167. Id. at $437-38$.

168. Id. at 437 n.9. Although the court was inclined to use book value, it did not, instead accepting an appraisal of current value.

169. Id. at 439-40.

170. Id. 
In Moody v. Security Pacific Business Credit, ${ }^{171}$ the court employed the piecemeal approach ${ }^{172}$ and actually came up with reasonable figures. However, even in that case, the court made a serious mistake. The target corporation valued its receivables at $\$ 7.929$ million at the time of the transaction, discounting for uncollectible accounts. ${ }^{173}$ Because the company was eventually able to collect $\$ 8.3$ million of its accounts outstanding as of the time of the LBO, the court increased the reconstituted receivables up to $\$ 8.3$ million-their value as actually collected. ${ }^{174}$ This analysis is flawed. It is well established that the frame of reference for solvency analysis should always be the time of the transaction. ${ }^{175}$ Courts and commentators have also wisely warned against the exercise of hindsight in valuation techniques. ${ }^{176}$

These cases compel several conclusions concerning the piecemeal valuation method. If a liquidation value is sought, then a piecemeal valuation of the target's financial data and the concomitant reconstruction of the balance sheet constitute a sound approach. On the other hand, if going concern values are required, the piecemeal approach is very undesirable. The whole theory of going concern value is that the whole can be greater or less than the sum of the parts; therefore, it is conceptually problematic to arrive at going concern values by summing figures from a reconstituted balance sheet. The margin of error is also greatly increased because so many small calculations are made and then added together. Furthermore, the process of going through the balance sheet item by item and trying to assign a going concern value to each item involves so much conjecture that courts lose confidence in the accuracy of their calculations. ${ }^{17}$ The courts then become quite eclectic as they reach out for a supplementary rationale upon which to base their decision. This wandering tempts courts

171. 127 B.R. 958 (W.D. Pa. 1991), affd, 971 F.2d 1056 (3d Cir. 1992).

172. Id. at $978-83$.

173. Id. at 978 :

174. Id. at 978-79.

175. Rosenberg, supra note 151, at 252; see, e.g., Murphy v. Meritor Sav. Bank (In re O'Day Corp.), 126 B.R. 370, 403-04 (Bankr. D. Mass. 1991); Clay v. Traders Bank (In re Briarbrook Dev. Corp.), 11 B.R. 515, 517-18 (Bankr. W.D. Mo. 1981).

176. See, e.g., Ohio Corrugating Co. v. DPAC, Inc. (In re Ohio Corrugating Co.) (Ohio Corrugating II), 91 B.R. 430, 438 (Bankr. N.D. Ohio 1988); Baird \& Jackson, supra note 22 , at $841-42$.

177. See Murphy, 126 B.R. at 402-04; Ohio Corrugating II, 91 B.R. at 437-40. 
to use the equity test of solvency, ${ }^{178}$ even though there is no mention of this test in the fraudulent conveyance statutes' definitions of insolvency. As a result, the piecemeal approach seems to have introduced an undesirable degree of uncertainty into the valuation process.

2. The "Holistic Approach" to Solvency Valuation. Although still evolving, this second approach to valuing companies for the purpose of a solvency analysis is in large part the brainchild of Judge Queenan of the Bankruptcy Court for the District of Massachusetts. ${ }^{179}$ According to Judge Queenan, courts should use a going concern valuation as long as the debtor's business is functioning as a going concern at the time of the LBO. ${ }^{180}$ On the other hand, if the debtor's business is on the verge of failure at the time of the LBO, the liquidation value should be used as an expedient because the going concern value is too difficult to calculate and because the going concern value is not much greater than the liquidation value anyway. ${ }^{181}$ Because LBOs do not usually involve companies in imminent danger of insolvency, going concern value should ordinarily be used as set out below.

Judge Queenan proffers two different methods of calculating the going concern value by means of the holistic approach. The first method simply utilizes the LBO purchase price as the going concern value of the company's equity. Judge Queenan describes this promising approach as follows:

The best evidence of Target's going concern value immediately after the sale will usually be the price paid in the LBO, as adjusted for the LBO transfers and obligations lacking [sufficient] consideration, provided that LBO interest payments do not turn profits into losses .... In arriving at Target's post-LBO value, downward adjustments should be made to reflect the transfers or obligations for which Target did not receive [sufficient] consideration. These adjustments would normally leave some positive value even if Target received absolutely no consideration. Typically, the buyer furnishes some portion of the LBO price from its

178. See Ohio Corrugating II, 91 B.R. at 439-40.

179. See Queenan, supra note 31 , at 15-17; Vadnais Lumber Supply v. Byrne (In re Vadnais Lumber Supply), 100 B.R. 127, 131-33 (Bankr. D. Mass. 1989) (Queenan, J.) (applying "holistic approach").

180. Queenan, supra note 31 , at 15.

181. See id. at 15-17. 
own small capital. This portion remains unaffected by any adjustment made to the pre-LBO price to reflect Target's transfers and obligations. Therefore, the LBO price as so adjusted should normally establish that Target had at least some minimal going concern value immediately after the transaction, thus making it solvent. ${ }^{182}$

As a simple illustration of the holistic approach, let us suppose that the purchase price of an LBO firm is $\$ 20$ million, the stock market had valued the firm at $\$ 17$ million, and the book value of the firm is $\$ 15$ million. Suppose further that $\$ 1$ million in cash is invested by the LBO investors and that the company is not on the verge of collapse before or immediately after the LBO. Lastly, the company pledges all of its assets as collateral to secure $\$ 19$ million of secured bank debt which the company now owes to the LBO lenders. The acquisition corporation is a shell with no significant equity.

Under the holistic approach, a going concern valuation would be appropriate. Twenty million dollars would be the appropriate going concern value. Next, the $\$ 19$ million in debt that the corporation incurred without receiving any consideration would be subtracted from the $\$ 20$ million. This would leave the corporation with a post-LBO going concern value of $\$ 1$ million. Hence the corporation is solvent.

The above analysis clearly would void as a fraudulent conveyance all LBOs in which no equity at all was used to finance the transaction or where the debt service from the LBO puts the corporation in the red right away. If the latter should occur, a liquidation valuation would be required and the target would almost certainly be found insolvent.

The benefit of this "holistic approach" is that it generally takes into account the true going concern value placed on corporations by the investment market. This awareness of market realities should assuage somewhat the fears of Baird and Jackson that all LBOs would effectively be invalidated by having fraudulent conveyance law applied to them. Furthermore, this approach is much more simple and predictable than the piecemeal valuation. If this view is widely adopted by the courts, then investors could be relatively certain that, as long as they put some equity down and

182. Id. at 15-16. 
as long as they did not immediately put the target in the red, the chances of fraudulent conveyance liability under a solvency analysis would be negligible.

The increase in certainty might make solvency letters more viable in the LBO context. Presently, few investment bankers or valuation firms are willing to provide meaningful solvency opinions because of the uncertainty in the law and the huge potential liability should the LBO fail. ${ }^{183}$ This reluctance has made it prudent for LBO participants not to seek a solvency opinion because the inability to procure a solvency opinion may be taken by a court as an indication of insolvency. ${ }^{184}$ If the "holistic approach" to solvency valuation is adopted, then investment bankers and other valuation experts will feel comfortable providing solvency letters, and the LBO participants would be secure in the knowledge that their LBO will not be invalidated as a fraudulent conveyance under the solvency provision. This would allow LBO participants to focus on performing due diligence to support the proposition that the LBO will not leave the corporation with "unreasonably small capital."

Judge Queenan recognizes a second well-known method of determining going concern value under the "holistic approach": valuation of the company based on a discounted, projected, future cash flow basis. ${ }^{185}$ As in the first method, the LBO must not turn profits into losses; if it does, liquidation value rather than going concern value is used. The debt service of the LBO should be accounted for in the capitalization of the earnings. ${ }^{186}$ This second

183. See In re Revco D.S., Inc., 118 B.R. 468, 491 (Bankr. N.D. Ohio 1990) (appendix containing the Preliminary Report of Examiner Professor Barry L. Zaretsky, July 16, 1990) (Revco's accountants provided the LBO target with a solvency letter that was so tentative that it was of little value.). Accountants are now precluded by their auditing standards from giving solvency letters in connection with LBOs. 1 AICPA Professional Standards $(\mathrm{CCH}) \S 9100.33-.46$. Attorneys also do not usually render legal opinions on solvency. Kirby et al., supra note 19 , at $48-49$.

184. See Joseph H. Levie, Do Solvency Letters Help? Or Are They Dangerous?, N.Y. L.J., Sept. 5, 1991, at 5, 6 n.12; see also Aluminum Mills Corp. v. Citicorp (In re Aluminum Mills), 132 B.R. 869, 877 (Bankr. N.D. Ill. 1991); Wieboldt Stores v. Schottenstein, 94 B.R. 488, 495 (N.D. IIl. 1988); .

185. See 1 JAMES C. Bonbright, ThE VAluation of Property 237-38 (photo. reprint 1965) (1937); 1 ARTHUR S. DEWING, THE FINANCIAL POLICY OF CORPORATIONS 287-90 (5th ed. 1953); GEORGE D. MCCARTHY \& ROBERT E. HEALY, VAluING A COMPANY 334-35 (1971); Queenan, supra note 31, at 16-17. For a more current discussion of this technique, see Isik Inselbag \& Howard Kaufold, How to Value Recapitalizations and Leveraged Buyouts, J. APPLIED CORP. FIN., Summer 1989, at 87.

186. Queenan, supra note 31 , at $16-17$. 
method involves much more complicated analyses. Financial determinations of terminal values, risk factors, growth rates, and so forth must be used in the calculations. Although liberal sensitivity analysis can provide strong support for a party's financial assumptions, there is still room for dispute as to which figures achieve a reasonable estimation of the present value of the firm's ability to generate cash in the future. As long as judges familiarize themselves with the complexities of this analysis, and as long as judges seek to articulate a fairly wide comfort zone, the second method of the "holistic approach" will be a viable means of determining solvency.

To the extent that the second method of the "holistic approach" to solvency analysis involves the reasonableness of financial projections, this method also addresses the same issue examined under the "unreasonably small capital" analysis. This overlap between the second method of the "holistic approach" and the "unreasonably small capital" analysis suggests that the first method of the "holistic approach" produces a more lucid jurisprudence. A consistent use of the first method of the "holistic approach" would limit the reasonableness inquiry to the "unreasonably small capital" analysis. The use of the first method of the "holistic approach" would also place the onus of the fraudulent conveyance inquiry on the "unreasonably small capital" analysis, because almost all LBO targets would be found solvent under the first method of the "holistic approach." This result is the best compromise between holding all LBOs to be fraudulent conveyances and exempting LBOs from fraudulent conveyance law. The resolution of fraudulent conveyance disputes would then come down to a battle of the experts over the reasonableness of the LBO participants' financial projections.

\section{D. "Unreasonably Small Capital" Analysis"}

If courts adopt the first method of the "holistic approach," then few LBOs will be fraudulent conveyances under the solvency

187. Although the UFTA substitutes "assets" for "capital," this change was intended to increase the linguistic precision of the provision; this substitution was not intended by the drafters of the UFTA to effect a change in the substantive law. See UNIF. FRAUDULENT TRANSFER ACT $\$ 4(a)(2)(i), 7 A$ U.L.A. 639, $654 \mathrm{cmt} .4$ (1985). Therefore, this Note will use the term "unreasonably small capital" to refer to this cause of action generally, despite the fact that the UFTA uses "assets." 
analysis. Then, the focus will shift from examining LBOs under a solvency analysis to examining LBOs under an "unreasonably small capital" analysis. This shift is conceptually satisfying because the focus of the inquiry really should be on the reasonableness of the parties' projections. Because it is very difficult to analyze these projections under the rubric of balance-sheet insolvency, it makes sense to address this issue squarely by analyzing the reasonableness of the target's capitalization.

Although determining what constitutes reasonable capitalization will be a difficult task for the trier of fact, at least the focus of the inquiry is on a concrete issue that can be resolved after hearing the testimony of both sides' expert witnesses. Having the fraudulent conveyance determination hinge on a reasonable capitalization test may still leave a great deal of uncertainty for people contemplating involvement in an LBO. Nonetheless, this result produces as coherent an analysis as can pragmatically be applied. If LBO venturers find even this uncertainty intolerable, they are free to lobby for legislative relief.

Unlike "insolvency," "unreasonably small capital" has no statutory definition. Determining whether a company is left with "unreasonably small capital" after an LBO is a highly fact-specific enterprise that implicates complex cash flow analyses ${ }^{188}$ similar to those used in the second method of the "holistic approach" to solvency valuation. Strangely, the "unreasonably small capital" provisions are much less well known and understood by both the bench and the bar. ${ }^{189}$ One commentator has denigrated the "unreasonably small capital" cause of action as being too vague and indefinite to ever be satisfactorily enforced. ${ }^{190}$ Although these comments are based on legitimate concerns, it would be premature to give up on this cause of action when standards are still being developed. ${ }^{191}$

"Unreasonably small capital" is, for the company, clearly a state of distress that is less severe than insolvency. Further, it is important to remember that "unreasonably small capital" is a

188. Cieri et al., supra note 20 , at 363.

189. See Queenan, supra note 31, at 24; Liss, supra note 75, at 1508.

190. Robert C. Clark, The Duties of the Corporate Debtor to Its Creditors, 90 HARV. L. REv. 505, 559 (1977); see also Liss, supra note 75, at 1508 (stating that the "unreasonably small capital" cause of action probably cannot be applied in a principled manner).

191. See, e.g., Bruce A. Markell, Toward True and Plain Dealing: A Theory of Fraudulent Transfers Involving Unreasonably Small Capital, 21 IND. L. REv. 469, 499 (1988). 
condition that is short of insolvency both in the bankruptcy and in the equity sense. ${ }^{192}$ Because insolvency in the equity sense is a more severe state of economic distress than being left with "unreasonably small capital," proof of equitable insolvency is necessarily proof of "unreasonably small capital." of section 2(b) of the UFTA should in no way change the analysis of LBOs under fraudulent conveyance law. ${ }^{194}$ Section $2(b)$ of the UFTA gives LBO fraudulent conveyance plaintiffs nothing more than what they already have under the "unreasonably small capital" cause of action. Section 2(b) does help other fraudulent conveyance plaintiffs who have no cause of action under the "unreasonably small capital" provision-for example, those creditors whose debtor is not a person engaged in business. ${ }^{195}$

As Judge Queenan stated in Vadnais Lumber Supply $v$. Byrne, ${ }^{196}$ "[u]nreasonably small capitalization therefore encompasses difficulties which are short of insolvency in any sense but are likely to lead to insolvency at some time in the future."197 In order to determine if the LBO target was sufficiently capitalized, one must analyze the financial cash flow projections of the company's post-LBO performance based on the facts at the time of the LBO. In order to be found reasonable these projections must make sense based on the LBO target's historical performance as reflected in its historical "cash flow, net sales, gross profit margins, and net profits and losses."198 The projections must take account of any difficulties likely to arise in the LBO target's busi-

192. Moody v. Security Pac. Business Credit, 971 F.2d 1056, 1070 (3d Cir. 1992); Murphy v. Meritor Sav. Bank (In re O'Day Corp.), 126 B.R. 370, 407 (Bankr. D. Mass. 1991) (quoting Queenan, supra note 31, at 18); Vadnais Lumber Supply v. Byrne (In re Vadnais Lumber Supply), 100 B.R. 127, 137 (Bankr. D. Mass. 1989).

193. See Moody, 971 F.2d at 1075-76.

194. See UNIF. Fraudulent TransFier ACT $\$ 2(\mathrm{~b}), 7 A$ U.L.A. 639, 648 cmt. 2 (1985) (burden of proof on legal insolvency shifts to the defendant if the plaintiff proves lack of sufficient consideration and insolvency in the equity sense).

195. See 11 U.S.C. $\$ 548(a)(2)$ (B)(ii) (1988); UNIF. FRAUDULENT CONVEYANCE ACT § 5, 7A U.L.A. 427, 504 (1985); UNIF. FrauduleNT TRANSFeR ACT $\$$ 4(a)(2)(i), 7A U.L.A. at 653 .

196. 100 B.R. 127 (Bankr. D. Mass. 1985).

197. Id. at 137.

198. Moody v. Security Pac. Business Credit, 971 F.2d 1056, 1073 (3d Cir. 1992); see Credit Managers Ass'n of Southern Cal. v. Federal Co., 629 F. Supp. 175, 184-86 (C.D. Cal. 1985). 
ness. ${ }^{199}$ They must leave a margin for error, for a general downturn in the economy, and for interest rate fluctuations. ${ }^{200}$

Courts are still trying to articulate a more substantial framework of analysis for determining the reasonableness of these projections of capitalization. To date, the cases applying this standard to LBOs have used common sense to determine the reasonableness of the presumptions underlying the financial analyses used to forecast the capitalization of the target. ${ }^{201}$ Although the courts focus on the projected cash flow from operations, courts will also consider the availability of additional credit and the availability of cash to be generated from asset sale programs planned at the time of the $\mathrm{LBO} .{ }^{202}$

Once again it is critical that courts not use hindsight, but rather that they scrutinize the situation of the company at the time of the LBO. ${ }^{203}$ The temptation to use hindsight makes this analysis difficult. Furthermore, assumptions in financial projections are subject to a wide diversity of opinion as to their reasonableness, and there is really no way of developing any semblance of objective criteria. So far, a crucial determinant in the cases has been the presence or absence of unexpected economic setbacks following the LBO that caused the debtor to require much more capital than ever could have been anticipated. ${ }^{204}$ Courts should try to

199. Moody, 971 F.2d at 1073; see Queenan, supra note 31, at 19.

200. See Moody, 971 F.2d at 1073; Queenan, supra note 31, at 19.

201. See Moody v. Security Pac. Business Credit, 127 B.R. 958, $996-98$ (W.D. Pa. 1991) (finding no fraudulent conveyance because the projections of target's management were reasonable and because the credit available to the new company was adequate to meet its needs for capital), affd, 971 F.2d 1056 (3d Cir. 1992); Credil Managers, 629 F. Supp. at 183-88 (finding no fraudulent conveyance because the projections were reasonable and because the credit was adequate); Murphy v. Meritor Sav. Bank (In re O'Day Corp.), 126 B.R. 370, 404-09 (Bankr. D. Mass. 1991) (finding "unreasonably small capital" where LBO participant used unreasonably optimistic projections; for example, the worst case scenario predicted financial performance superior to any experienced by the company in years); Vadnais Lumber Supply v. Byrne (In re Vadnais Lumber Supply, 100 B.R. 127, 137-40 (Bankr. D. Mass. 1989) (finding target left with "unreasonably small capital" because the LBO participants did not provide a sufficient means for the target to obtain future credit where the corporation received absolutely no new capital and where the company was clearly having a bad year already).

202. See Moody, 127 B.R. at $996-98$ (operating cash flow and availability of credit); Vadnais Lumber Supply, 100 B.R. at 137-39 (operating cash flow, asset sales, and availability of credit); Credit Managers, 629 F. Supp. at 183-88 (operating cash flows and availability of credit).

203. Credit Managers, 629 F. Supp. at 185-87; Queenan, supra note 31, at 19-20; see also Cieri et al., supra note 20, at 364 (warning that courts may use 20/20 hindsight and be influenced by events that occurred subsequent to the LBO).

204. Compare Credit Managers, 629 F. Supp. at 184-88 (a strike by employees, the 
give a fair amount of deference to the LBO participants' assumptions (as long as they used conventional financial analyses); but at the same time, they should not let LBO participants avoid liability without establishing reasonable capitalization.

\section{CONCLUSION}

Despite the ancient origins of fraudulent conveyance law, there is no reason why these statutes should not be applied to LBOs. The LBO falls well within the broad language of fraudulent conveyance statutes so that it would require a scandalous excess of judicial activism in order to legislate an exemption for LBOs from fraudulent conveyance law. Furthermore, twenty-nine states have recently revised their fraudulent conveyance laws, yet not one has exempted LBOs from the reach of these statutes.

In applying fraudulent conveyance law to LBOs, courts should be very careful to utilize legal standards and valuation techniques that accurately parallel and reflect the expectations of the business community (for example, their expectation that they can borrow on the reasonable projections of a company's future performance). Yet at the same time courts must enforce some normative standards upon business investors in order for the statutes to have some kind of content.

Few plaintiffs will be able to prove that an LBO was intentionally fraudulent. Therefore, plaintiffs will focus on the constructive fraud provisions. In the context of the typical transaction, few LBOs will be able to meet the sufficiency of consideration requirements of the constructive fraud provisions because the courts will view the transaction in the aggregate and from the viewpoint of the target's creditors. The courts wil] focus on the value added to the target corporation and the value subtracted from the corporation as a result of the LBO, and will not be deterred by structural niceties or labels that seek to disguise the true nature of the transaction. Instead of becoming preoccupied with the "knowledge or intent" of the LBO participants, courts ought to keep the analysis simple and collapse the transactions as a matter of course.

bankruptcy of large customer, and a general downturn in the market all required more capital than could have reasonably been expected at the time of LBO) with Vadnais Lumber Supply, 100 B.R. at 138-41 (adversity that put company in bankruptcy could have been anticipated and provided for at the time of LBO). 
Because most LBOs realize little direct benefit for the target corporation, the corporation is likely to pass muster under the sufficiency of consideration test only if it receives substantial indirect benefits. Such indirect benefits probably will only arise when the LBO involves more than one operating company. The target may then be able to either recognize a synergy through its relationship with the other company or receive a valuable corporate guarantee.

Bankruptcy courts face difficult valuations in various areas of bankruptcy law, especially when the court must value a company whose viability as a going concern is in doubt. Courts should do their utmost to see that corporations are responsibly valued in proceedings under bankruptcy law. Although the transactions and corporations involved in LBOs are often complex and large, the valuation problems implicated in applying fraudulent conveyance law to LBOs are not much different from the valuation problems faced elsewhere under the Bankruptcy Code.

Although the UFCA definition of solvency means that the phantom of equitable insolvency still haunts the fraudulent conveyance law of nine jurisdictions, the UFTA should greatly harmonize the solvency analysis as between state and federal fraudulent conveyance law. This harmonization is a positive result because insolvency in the bankruptcy sense is a more workable standard under which sound valuation methods can be cultivated in the caselaw.

Although it is correct to scrutinize the balance sheet of a corporation in order to get a handle on the economic status of the target at the time of the LBO, the piecemeal approach is flawed because it is more speculative, more complicated, and less certain than the "holistic approach." All of these factors make the piecemeal approach conducive to uncertain, unclear, and unsound jurisprudence.

Judge Queenan's "holistic approach" has the benefit of simplicity; and it also respects the reliance of LBO investors on going concern values that are higher than the market price or book value of the corporation. Nonetheless this approach still places strictures on investor behavior by requiring some minimal equity contribution and enough income in the years after the LBO to adequately service the LBO debt.

The "unreasonably small capital" analysis has not often been used, and there is considerable room for development in the caselaw. "Unreasonably small capital" is a status that is near both equitable and legal insolvency, yet somewhat more economically 
favorable than these two situations. There is no statutory definition of this standard. The cases to date have turned mainly on the reasonableness of the LBO participants' financial projections as well as on the degree to which extraordinary external forces helped precipitate the target's plunge into insolvency some time after the consummation of the LBO.

If one adopts the "holistic approach" to solvency analysis, then it is crucial to develop a more rational "unreasonably small capital" analysis, because the "holistic approach" (especially the first method) will void fewer transfers as fraudulent conveyances than do other approaches to solvency analysis. Therefore, it is important that a sound "unreasonably small capital" analysis evolve to satisfy the need for a rational standard that can be reasonably applied.

This situation will likely result in a less intrusive fraudulent conveyance law than would be the case under other regimes. The "holistic approach" grants the LBO investors a wide degree of latitude in bargaining for the price of the target corporation. All that it requires is an equity input of some sort and that the company not go into the red soon after the LBO. If the LBO passes this test, then the "unreasonably small capital" analysis can inquire into the LBO participants' foresight in providing sufficient working capital for the effective operation of the company. As the caselaw in this area develops, courts should take care not to indulge in hindsight. Courts in this area should familiarize themselves with the fundamentals of discounted cash flow analyses in the LBO context. Then, the articulation of "unreasonably small capital" law can evolve on a case-by-case basis.

Legislative regulation of LBOs would be welcome by judges, but it is unlikely to occur. Absent such regulation or the passage of express exemptions for LBOs from fraudulent conveyance liability, judges can and must create an effective body of law that applies fraudulent conveyance standards to LBO transactions. By exercising wisdom and intelligence in forming such a body of law, judges can create workable fraudulent conveyance standards for LBOs. 